\title{
SECTION 37 \& THE CREATIVE CITY HOW DENSITY BONUSES HAVE SECURED CULTURAL BENEFITS IN THE CITY OF TORONTO
}

\author{
by \\ Meaghan Davis \\ B.A. (Hon.), McGill University, 2009 \\ A Major Research Paper \\ presented to Ryerson University \\ in partial fulfillment of the requirements for the degree of \\ Master of Planning \\ in \\ Urban Development
}

Toronto, Ontario, Canada, 2016

(c) Meaghan Davis, 2016 


\section{AUTHOR'S DECLARATION FOR ELECTRONIC SUBMISSION OF A MRP}

I hereby declare that I am the sole author of this MRP. This is a true copy of the MRP, including any required final revisions.

I authorize Ryerson University to lend this MRP to other institutions or individuals for the purpose of scholarly research

I further authorize Ryerson University to reproduce this MRP by photocopying or by other means, in total or in part, at the request of other institutions or individuals for the purpose of scholarly research.

I understand that my MRP may be made electronically available to the public. 


\author{
SECTION 37 \& THE CREATIVE CITY \\ HOW DENSITY BONUSES HAVE SECURED CULTURAL BENEFITS \\ IN THE CITY OF TORONTO \\ (c) Meaghan Davis, 2016 \\ Master of Planning \\ in \\ Urban Development \\ Ryerson University
}

\begin{abstract}
Section 37 of the Planning Act authorizes Ontario municipalities to permit developments to achieve greater height and density than otherwise allowed in exchange for community benefits. Although land use planners rarely take a leading role in arts policy discussions, this planning tool has been identified as an important opportunity to support and grow Toronto's arts and culture sector. This research project investigates how Section 37 agreements have been used to secure spaces for cultural production and dissemination in the City of Toronto. A mixed-methods approach is used to quantify these benefits and their distribution throughout the city, and to probe the experiences of cultural organizations in order to better understand who and what is relied upon to build new cultural spaces. The study concludes that land use planners must reinvent their approach to cultural planning and make proactive use of planning tools in order to support Toronto's creative city goals.
\end{abstract}

Key words: Section 37, density bonus, cultural planning, community benefit, cultural infrastructure, performing arts venue 


\section{Acknowledgements}

This project would not have been possible without the support and guidance of my research supervisor, Dr. Pamela Robinson. Over the past two years I have learned so much through her wisdom, critical perspective, rigorous ethics, and endless enthusiasm. No student has ever had a greater cheerleader.

I am also grateful to Robert Millward for generously serving as the second reader for this project; and to Jeff Biggar, whose work on a Section 37 database helped to catalyse the research process.

This project has benefited from contributions and suggestions offered by many people over the past year, particularly: David Amborski, Artscape, Franco Boni, Mitchell Cohen, Noel Damba, Robert Foster, Niall Haggart, Carolyn Humphreys, Joe Lobko, Lori Martin, and Susan Wright. I am so thankful to my friends and instructors at the Ryerson School of Urban and Regional Planning for their support and inspiration, especially Anna Golovkin; and to Paul Flude, who was there for every site visit, analytical hurdle, and emotional meltdown. This master's degree has truly been a team effort. 


\section{Table of Contents}

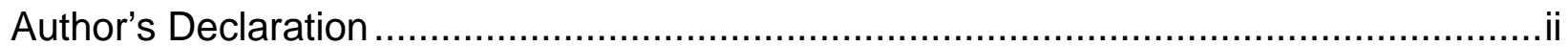

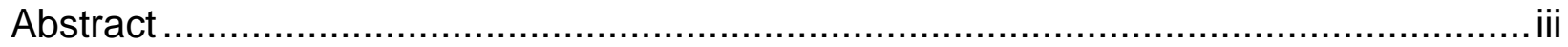

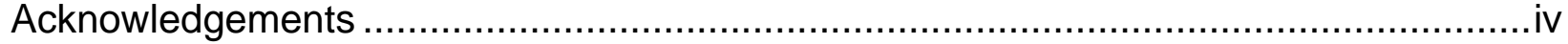

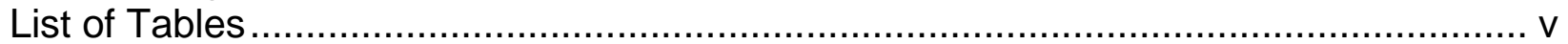

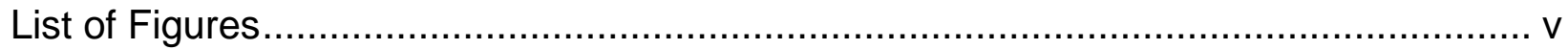

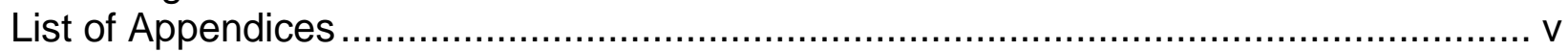

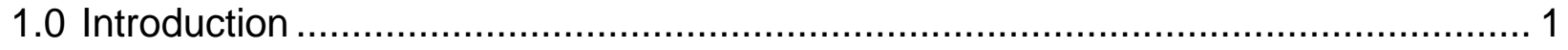

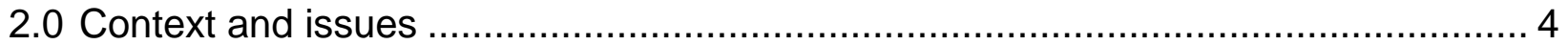

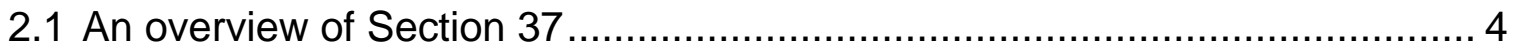

2.2 Cultural planning in Ontario and Toronto ............................................. 11

2.3 The intersection of Section 37 and cultural planning in Toronto ................. 17

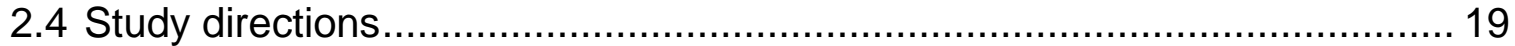

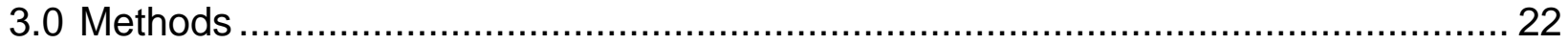

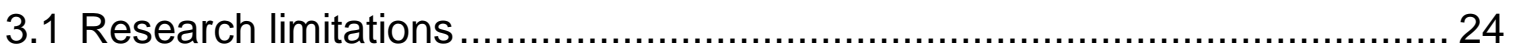

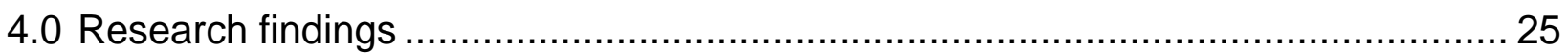

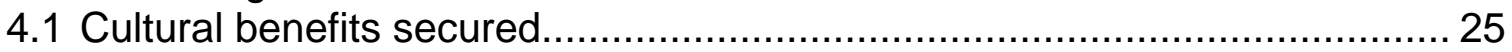

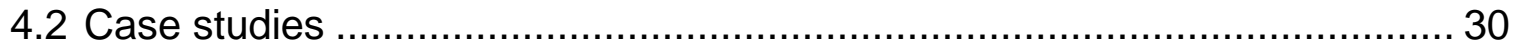

4.3 Case studies: emergent themes..................................................... 40

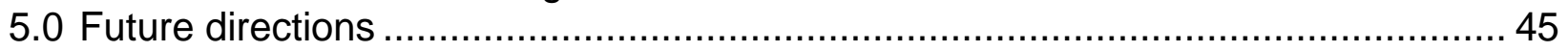

5.1 Reinvent the relationship between land use and cultural planning ..............46 46

5.2 Make proactive use of existing planning tools ......................................... 48

5.3 Close the research gaps ..................................................................... 49

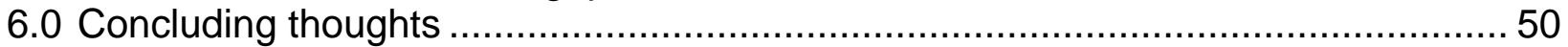

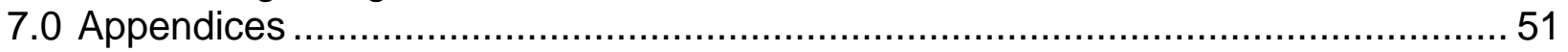

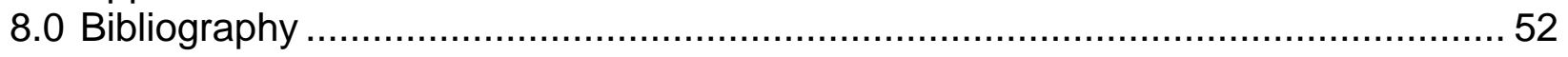

\section{List of Tables}

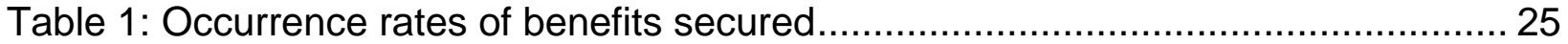

Table 2: Occurrence rates of arts and culture benefits secured ................................. 26

\section{List of Figures}

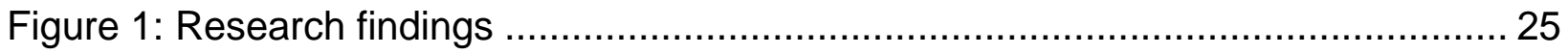

Figure 2: Section 37 agreements that name cultural benefits ................................. 27

Figure 3: Instances of benefits named in Section 37 agreements .............................. 28

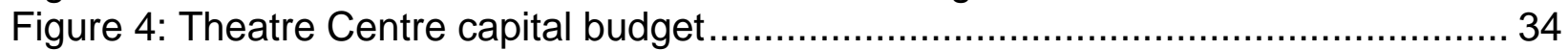

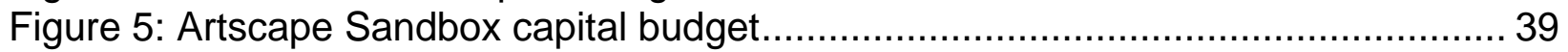

Figure 6: Land use and culture planning at the City of Toronto ................................... 46

\section{List of Appendices}

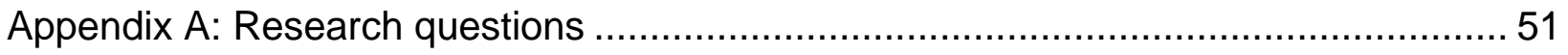




\subsection{Introduction}

"Access to the arts and culture for all is a vision for change. Cultural participation, in all its forms, from now on has become a goal to strive for, so that big cities don't fall apart due to economic, social, linguistic, and cultural disparities. By investing more in cultural participation, public art, artistic productions, and artistic and cultural programs in schools, we can only improve creativity, free thinking, and citizens' ability to live together."

Simon Brault, No Culture, No Future

In 2009, Simon Brault - now head of the Canada Council for the Arts - penned a manifesto on arts and culture that has made a lasting impact on the Canadian culture sector. No Culture, No Future presented a vision of civic life rooted in cultural participation, arguing that culture is a strong indicator of the health and sustainability of a municipality. A people's inalienable right to access and participate in their culture justifies government intervention and support (Brault, 2009). Indeed, there is a broad spectrum of arts activities, from the grandest symphony to the most modest fingerpainting, that thrives separate from - and sometimes in spite of - market pressure.

Brault argued that, in the darkest moments of human history, cultural expression has been a fundamental part of human survival. Seven years later, the urgent need for the restorative and transformative influence of arts and culture endures. In a historical moment marred by ethnic tension and cultural violence, where terrorism oversees manifests in racially-motivated attacks on individuals and religious spaces here in Canada, there has never been a more critical time to invest in spaces for people to come together to celebrate, to grieve, and to learn from one another.

Cultural investment would seem like an obvious policy direction in a city like Toronto that lauds its own cultural diversity. Yet the rhetorical support for culture has not always been matched by tangible public sector commitments at the municipal, provincial, or federal levels. Although arts funding levels have generally been restored following significant cuts in the 1990s, the higher number of arts groups now vying for support forces public agencies to issue smaller grants in an attempt to spread limited funds as broadly as possible (Marsland, 2013). In response, arts organisations are cultivating a growing reliance on private sector philanthropy and sponsorships (Jenkins, 2005). Given the current limits of public investment, alternative mechanisms are required to carve out space for cultural activity and secure the funding required for this activity to flourish. 
Though land use planners rarely take a leading role in arts policy discussions, they influence an important tool that is currently being used to support new cultural infrastructure development. Section 37 of the Planning Act offers municipalities a mechanism to extract community benefits from developers in the Province of Ontario. As a funding tool it is exceptionally polarising: whereas some critics have described Section 37 as a shakedown against developers, others have seized the opportunity to use this tool to support community engagement and empowerment (Keenan, 2015). As such, with more than 600 Section 37 agreements written or implemented, the City of Toronto could equally be described as the most prolific or the most notorious user of the planning tool.

In the face of mounting Section 37 criticism, one sector that has consistently expressed its enthusiasm for the policy is Toronto's arts and culture community. Section 37 has been identified as a funding opportunity by a range of parties, including cultural planners (City of Toronto, 2003; Creative Capital Advisory Council, 2011; Millward, 2013), sector advocates (ArtsVote Toronto, 2014), and Toronto's leading not-for-profit art space developer (Artscape Toronto, n.d.f). This enthusiasm is understandable given the scale and pace of development in Toronto. Provincial legislation that concentrates growth in existing urban areas has served to reduce land supply, which consequently increases both land values and the risk of displacement (Lehrer \& Wieditz, 2009). Communities of artists may be particularly vulnerable to development pressures given the average Canadian artist makes only $\$ 32,000$ annually (Hill Strategies Research Inc., 2014), and that Toronto's municipal funding commitments to the arts sector have historically lagged behind other major Canadian cities (Hill Strategies, 2012).

There is high demand for land in the City of Toronto and increasingly short supply, particularly for not-for-profit organisations that lack the financial resources to compete with market-oriented projects. With the price of a single Toronto apartment averaging nearly $\$ 350,000$ (Toronto Real Estate Board, 2016), large footprints at streetlevel are increasingly out of reach to community-oriented uses that enliven streets and foster complete communities. As such, it is critical that planners consider not only what assets are needed to build a vibrant and liveable city, but what unique demands and strategies are necessary to ensure these assets are realised. 
Section 37 has become a high profile component of Toronto's community development toolkit. Although the City has issued a report on the use of Section 37 for securing cultural benefits, little scholarly research exists that explores this planning tool in the context of cultural infrastructure provision. As such, this paper strives to nuance our understanding of the planning tool by exploring how it has contributed to the provision of cultural amenities in the City of Toronto. The intent of this paper is not to solve the myriad legal, political, and theoretical problems associated with Section 37. Rather, this paper offers land use planners a window into the culture sector by articulating the experiences of not-for-profit groups that have participated in the Section 37 process. By exploring what Section 37 of the Planning Act has achieved for Toronto's culture sector, and what the opportunities and limitations of this funding stream may be, this paper strives to build bridges between land use planning and culture so that planners can better serve this dynamic and vital sector. 


\subsection{Context and issues}

The following section outlines the history and policy contexts that inform this research project. It begins with an analysis of Section 37 of the Planning Act, which emphasises how this planning tool has been used by the City of Toronto. Next, Toronto's cultural planning framework is reviewed, followed by a discussion of how Section 37 and cultural planning intersect in policy documents. Finally, these items are synthesised to identify the research gaps that will be explored by this project.

\subsection{An overview of Section 37}

The planning profession is tasked with navigating the balance between, on the one hand, enabling developers to make money constructing private spaces on an increasingly limited supply of land; and, on the other, enabling the public sector and communities to extract social goods from these private gains. Density bonusing has historically been one mechanism to address the needs of both the public and private sectors. At its most basic, Section 37 (s. 37) of the Planning Act authorizes municipalities in Ontario to permit developments to achieve greater height and density than otherwise allowed in exchange for community benefits (Doumani and Foran, 2014; Gladki Planning Associates, 2013; Kelly and Enta, 2013; Moore, 2013a, 2013b; R.E. Millward and Associates Ltd., 2013). In recent years this financing tool has generated legal and scholarly commentary (Doumani and Foran, 2014; Kelly and Enta, 2013, Moore, 2013a, 2013b), criticism from policymakers and community members ("John Tory wants full review of section 37 contributions," 2015; Lancaster and Bridge, 2015; Whyte, 2015), and has been cited as an opportunity for non-profits and community groups to maintain their presence in Canada's largest city while it experiences tremendous growth and intensification (City of Toronto, 2003; Creative Capital Advisory Council, 2011; Millward, 2013; Sandals, 2013). The Province of Ontario has also recently introduced new legislation that will influence the future implementation of s. 37 agreements (Bill 73, 2015). As such, a clear understanding of the opportunities and constraints of $\mathrm{s} .37$ has never been more relevant. 


\subsubsection{What is Density Bonusing?}

Through density bonus agreements, municipalities strive to capture a portion of the value of the "uplift" (Moore, 2013b, p. 13) created by rezoning a property and redirect it toward public goods. A developer is able to earn a greater profit when they can build higher and denser. The uplift corresponds to the difference between the base value of a property and its higher, rezoned value. Density bonus agreements can serve a redistributive function by redirecting a portion of that value to community needs; however, the extent of their redistributive capacity is constrained by the bonusing regulations set out by municipal and provincial legislation.

Jurisdictions across North America permit density bonusing, often employing a systematic approach to calculate the increased density possible with the aim to secure a single, predetermined type of benefit (Moore, 2013b). In the United States, many density bonusing policies were introduced to secure affordable housing in jurisdictions where the courts struck down inclusionary zoning as an illegal tax (Moore, 2013a, 2013b). Density bonusing provisions were first introduced in Canadian municipalities in the late 1800s, although the practice was eliminated in all provinces until the midtwentieth century on the grounds that it led to unfair treatment and abuses by recipients of the bonuses (Kitchen, 2002). It was in 1983, with the introduction of the former Section 36 of the Planning Act, that Ontario municipalities first received legal authority to generate public benefits from new developments (Doumani and Foran, 2014).

There is considerable incentive for a developer to enter into a density bonus agreement. The cost of providing a community benefit is greatly outweighed by the potential return they can achieve through this conditional rezoning (Moore, 2013b). Thus, where developers do not recognise either a financial rationale or an ethical imperative to provide public goods, density bonusing regulations can play a productive role by distributing the returns of urban development more widely throughout a community. The Ministry of Municipal Affairs and Housing (MMAH) similarly acknowledges there are benefits for municipalities that enter into s. 37 agreements:

- They can support community building objectives like intensification, growth management, and increasing transit supportiveness; 
- They can enhance new developments and existing neighbourhoods with attractive visual amenities;

- And they can provide facilities and services that serve communities "without increasing the financial burden on municipalities or their taxpayers" (Ministry of Municipal Affairs and Housing, 2016, emphasis added).

The suggestion that s. 37 agreements are an alternative revenue stream to secure public goods is inconsistent with the Ontario Municipal Board (OMB) decision in Sterling Silver Development Corp. $v$ Toronto (2005), which is regularly referenced in literature on the topic:

...the Planning Act is not a revenue statute. For its part, s. 37 is neither a municipal capital gains tax, nor a tool for municipalities to sell upzonings to supplement their coffers. As a component of the Planning Act, its use must be governed by the principles of planning and the objectives of the Act. In short, there must be a nexus between the development and the s. 37 benefits, demonstrating that the benefits pertain to the development (whether on-site or off), not to unrelated municipal projects (no matter how meritorious). (Doumani and Foran, 2014, p. 88, footnote)

The "nexus" between benefit and development is a recurring theme in case law and municipal policy (Moore, 2013a) and it is commonly interpreted to mean a geographic relationship (Doumani and Foran, 2014; Gladki, 2014; Kelly and Enta, 2013; Millward, 2013; Moore, 2013a, 2013b; Toronto, 2010). The OMB has made it clear that developers are entitled to a transparent and predictable process when determining if a s. 37 agreement is necessary, what its value ought to be, and how the benefit relates to the proposed development (Kelly and Enta, 2013). As such, s. 37 only has the capacity to redistribute the wealth generated by new development within a targeted local context. In its present form, the tool is not designed to address gaps in amenity provision throughout a municipality.

All s. 37 agreements must past a two-part test established in Toronto (City) $v$ Minto: the increased height and density must constitute good planning, and the community benefits must be consistent with official plan policies (Kelly and Enta, 2013). 
Consequently, s. 37 has been described as a "limited bonus zoning authority" (Doumani and Foran, 2014) insofar as the exchange of benefits is conditional upon the existence of the appropriate municipal planning policies. However, for the same reason, some commentators question whether it is appropriate to refer to a s. 37 agreement as a density bonus at all. In a report produced for the City of Toronto, R.E. Millward and Associates argue that benefits secured through these agreements "are not the result of a bonus as the development density has already been deemed appropriate" (2013, p. 3). Moore (2013b) further argues that s. 37 agreements do not constitute density bonuses in the traditional sense of the term because they are not systematic, are negotiated in an ad-hoc manner, and are used to secure a wide range of benefits rather than a specific policy goal. Comparisons between s. 37 and density bonuses used in other jurisdictions are limited by differences in legislation, governing structures, and context-specific financial considerations (Gladki, 2014; Millward, 2013; Moore, 2013b). Although s. 37 agreements are not a common practice across the province, a growing number of municipalities are exploring opportunities to use this tool and are considering the lessons learned to date in its application (Gladki, 2014; Kelly and Enta, 2013; Millward, 2013).

\subsubsection{Section 37 in the City of Toronto}

The City of Toronto has a more extensive history with s. 37 agreements than any other Ontario municipality (Gladki, 2014; Kelly \& Enta, 2013). Through s. 37, the City has secured \$309 million in cash benefits and \$212 million in payments and accrued interest since Toronto was amalgamated in 1998 (Gladki, 2014). Though unquantifiable, the value of in-kind contributions secured through s. 37 agreements may be well in excess of these figures (Moore, 2013a). As such, the Toronto experience is often scrutinised to inform possible implementation strategies in other municipalities.

Chapter 5.1.1 of Toronto's official plan (2010) authorises the use of s. 37 agreements to conserve heritage resources, to conserve or replace rental housing, to secure benefits identified in secondary plans, and to secure capital facilities that support development. These facilities can include non-profit daycares; public art; non-profit arts, cultural, community, or institutional facilities; parkland or park improvements; access improvements to ravines and valleys; streetscape improvements; purpose built, 
affordable or mid-range rental housing; improvements to transit facilities; land for municipal purposes; and other local improvements as identified by plans and studies. At present, only four secondary plans directly name arts and culture as benefits that ought to be secured through s. 37 agreements or density incentives. Moore's (2013a, 2013b) comprehensive study of Toronto's s. 37 agreements found that streetscape amenities and visual improvements were the most common benefit secured.

In the City of Toronto, a s. 37 agreement can be considered when a development requests significantly more height or density than the existing zoning permits and involves a minimum 10,000 square metres of gross floor area; however, City staff must first assess the appropriateness of the existing by-law in order to determine whether a s. 37 agreement can be reasonably required to permit the increase (City of Toronto, 2010; Millward, 2013; Moore, 2013b). Official plan (2010) chapter 5.1.1, policy 5, also permits the use of $\mathrm{s} .37$ agreements regardless of the size of the development where a secondary plan or area specific policy prevails. This provision can create opportunities to invoke s. 37 in parts of the city where large-scale development is less likely to occur, provided municipal planners proactively identify areas where community benefits should be a component of development applications.

On average, Toronto planners endeavour to secure benefits worth $15-20 \%$ of the value of the increased height and density permitted on the property (Moore, 2013a). However, the City's (2007a) implementation guidelines for the use of s. 37 state clearly that no city-wide formula can be applied to determine the value of s. 37 contributions. Each agreement receives a unique valuation process that considers the site context and surrounding community (Millward, 2013). These policies reflect the desire to avoid conflict at the OMB over whether or not s. 37 constitutes an illegal tax (Moore, 2013a, 2013b). The rationale that establishes the value of benefits is not immediately evident to parties outside the negotiation process. Consequently, it is impossible for a member of the public to make an informed assessment as to whether the amount of the contribution is fair or appropriate.

Although the City Planning and Real Estate Services Divisions are responsible for determining the value of the s. 37 agreement, it is the ward councillor who negotiates the type of benefits and how they should be allocated. The councillor is also entitled to 
ignore the recommendations made by planning staff regarding the type of benefit that should be secured (Moore, 2013a). Moore (2013b) argues that the councillor's highly subjective influence leads to a lack of clear policy or planning justification in the application of s. 37 agreements in Toronto. Conversely, Kelly and Enta (2013) suggest that the ward councillor plays an important part in the negotiation process by ensuring community needs are accurately represented and that benefits secured are tailored to these needs. Political and public participation may create greater accountability and increase the likelihood that the community will support the development. In practice, however, opportunities for the public to participate in this process are limited and tend to occur at the end of the negotiation process, if at all (Gladki, 2014). The ad-hoc, unpredictable nature of s. 37 may serve to undermine its regulatory value. This is especially problematic if the lack of transparency and consistency makes it difficult for negotiating parties to trust one another.

\subsubsection{Issues and Controversies}

Moore's (2013a, 2013b) research offers one of the most comprehensive analyses of the City of Toronto's use of s. 37 agreements. The author argues that, considered side-by-side, the language employed by the City of Toronto, the MMAH, and the OMB leads to complicated interpretations over whether s. 37 community benefits are meant to support good planning, or whether these proposals ought to qualify as good planning independent of the provision of community benefits. Similarly, Moore questions why municipalities are entitled to any of the value of the uplift, citing three problematic rationales that are used to justify the use of bonusing agreements. Firstly, the argument that s. 37 ought to fund the infrastructure required to service new development is undermined by the fact that the Development Charges Act already serves this purpose. The argument that s. 37 agreements should serve a redistributive purpose conflicts with the requirement that there be a nexus between the benefit secured and the new development. Finally, the argument that s. 37 ought to compensate communities negatively affected by increased density is doubly problematic. On the one hand, Moore argues, a compensatory rationale contradicts the City requirement that development proposals represent good planning prior to the provision of $\mathrm{s} .37$ benefits. On the other hand, this rationale overlooks the fact that 
increased density can also have positive effects in a community, and that intensification is a planning priority for both the City and the Province. Ultimately, Moore's study found that $\mathrm{s} .37$ benefits are most commonly positioned as a means to compensate residents for the negative effects of increased height and density.

Despite its implementation guidelines and negotiation protocol, Toronto's use of s. 37 agreements has created a considerable degree of controversy. The tool has been broadly criticised by planners, developers, politicians, media, and the public (Whyte, 2015), most often on the grounds that the process lacks transparency and accountability (Moore, 2013a, 2013b). In a general critique of density bonusing, Kitchen (2002) argues the mechanism may lead to inequities and inefficiencies, and that it undermines the use of zoning by-laws as a tool to control urban development. If zoning by-laws represent sound planning, the author asks, why would the provision of a benefit affect the rationale of the in-force policy? Similarly, in instances where the current zoning is out of date, the value of the uplift can be arbitrary and consequently easy to abuse (Moore, 2013b).

In Toronto, these criticisms came to a head in January 2015 over a condo development in the Mimico neighbourhood. According to residents, the ward councillor reduced a benefit agreement worth $\$ 250,000$ by $\$ 100,000$ with no explanation for the reduction (Lancaster and Bridge, 2015). This move prompted one resident to file a complaint with the City's integrity commissioner (Bridge and Lancaster, 2015) and drove Mayor John Tory to call for a review of the City's s. 37 practices ("John Tory wants full review," 2015). Shortly thereafter, the Province of Ontario announced Bill 73, the proposed Smart Growth for Our Communities Act, which includes a series of amendments to s. 37 of the Planning Act. Among the changes are new accounting requirements that identify the funds spent and received through s. 37 agreements, and name the specific facilities they were used for; as well as a requirement that this information be made available to the public (Bill 73, 2015). It remains to be seen how Bill 73, once implemented, will affect the use and perceptions of s. 37 agreements in Toronto. As Moore (2013b) observes, better accounting may do little to address whether density bonusing is an appropriate or justified mechanism to achieve planning goals. 
Proponents of s. 37 counter these criticisms by arguing the agreements represent a vital component of good planning that helps to integrate a proposed development with its neighbourhood context (Gladki, 2014). Benefits are also essentially guaranteed to the community because they are secured in by-laws passed by City Council (Millward, 2013). This level of security is not common to the sources of funding typically available to not-for-profit initiatives, which can make s. 37 an attractive revenue stream. This may be especially enticing for the field of culture planning, which has been challenged to serve the needs of growing communities of artists and strengthen Toronto's competitive position without creating additional burdens for the property tax base in the process.

\subsection{Cultural Planning in Ontario and Toronto}

"A great city offers and promotes a vibrant cultural life. It recognises the contribution the arts make to the quality of life of its residents. For Toronto to become one of the great cities of the $21^{\text {st }}$ century, we will need to nurture leading-edge imagination and build on the strength of our rich diversity of cultural expression."

Toronto Official Plan

\subsubsection{What is Cultural Planning?}

Cultural planning is a well-established though sometimes loosely defined discipline within the broader planning profession. The earliest North American approaches understood cultural planning to marry culture and social sciences with the traditional aspects of urban planning, including urban design, economic development, education, and equity (Jones, 1993). Efforts were made to distinguish the new discipline from traditional arts policy through an emphasis on mapping and analysing cultural assets, rather than advancing particular cultural or artistic forms (Kovacs, 2011). Like all planning disciplines, cultural planning recognises that great cities do not happen by chance. Government support and market intervention help to create the conditions that enable culture to flourish.

At a local level, cultural planning leverages arts, culture, heritage, and other cultural resources to stimulate urban and community development (Grodach, 2013; Kloosterman, 2014). Culture plans acknowledge the arts contribute to community growth, strive for the efficient distribution of scarce resources, and serve to generate public support and funding for the sector (Jones, 1993). They outline a high level vision 
that recognises the arts as an essential service, and offer recommendations as to how this vision could be achieved (Bain, 2013). McDonough and Wekerle (2011) argue that cultural planning in Ontario since the 1990s has involved a concerted policy effort to leverage a municipality's cultural assets in support of its urban development goals. By using an inclusive definition of culture, cultural planning is able to encompass a broad range of activities, forces, and urban elements; although this breadth can make it difficult to distinguish cultural planning from other planning practices (Kovacs, 2011). The overarching descriptions of cultural planning suggest an impressive capacity to support city-building initiatives and pursue the public good. Yet despite its promise, cultural planning does not feature prominently in the policy framework that governs land use planning in Ontario. The separation between the disciplines is a recurring theme in both academic and professional literature.

\subsubsection{Culture planning in Ontario}

Provincial planning legislation is generally supportive of cultural planning, though it provides little in the way of specific guidance for municipalities as they pursue culturebased initiatives. The Provincial Policy Statement, 2014 (PPS) recognizes the environmental, economic, and social benefits of cultural heritage. Cultural planning is identified in Section 1.7.1 as a means to support long-term economic prosperity, while Section 2.6 promotes the use of cultural plans to conserve cultural heritage and archaeological resources (MMAH, 2014). The PPS provides high-level directions only; its focus is predominantly on matters of land use, and as such it makes little reference to the contents of cultural plans and their more qualitative features. Guidance for cultural planners must be sought outside of the MMAH in the Ministry of Tourism, Culture, and Sport, where the first Culture Strategy for Ontario is currently being developed (Ministry of Tourism, Culture, and Sport, 2015). The Province has also recently released the first phase of its planning framework for community hubs (Advisory Group on Community Hubs, 2015), which has garnered attention from Toronto arts groups and policymakers interested in expanding cultural infrastructure to areas outside of the downtown core (Artscape, n.d.e). Though an Ontario-wide culture plan is a very recent initiative, the Province's Creative Communities Prosperity Fund was established in 2009 to support municipalities and Aboriginal communities 
undertaking cultural planning (Municipal Cultural Planning Inc., 2011). Research by Kovacs (2011) found more than half of Ontario's mid-sized municipalities have since produced cultural plans.

The most substantive guidance for cultural planners is contained in municipal policies and reports. In Toronto, these documents are predominantly guided by the discourse of creative cities. The creative city ethos holds creativity to be the linchpin of economic growth and innovation, taking an instrumental approach to culture as a way to attract new residents and create high quality places (Grodach, 2013). Although the City of Toronto has been formally invested in the culture sector since the late 1950s, it was not until the late 1990s that the creative city movement began to take hold (Grodach, 2013; York University, 2008). When the Province amalgamated the municipalities of Toronto, East York, Etobicoke, North York, Scarborough, and York into a single entity in 1998, the restructuring presented an opportunity to establish a division within the new municipal structure that was dedicated to cultural planning (McDonough and Wekerle, 2011). Within five years the amalgamated City of Toronto had a new official plan and its first culture plan: the Culture Plan for the Creative City.

\subsubsection{Toronto's Culture Plans}

The Culture Plan (2003) set out a 10-year vision for cultural development rooted in the argument that culture is essential for economic return and global competitiveness. The document positioned the facets of creative cities - arts and culture, high quality educational institutions, vibrant street life, diversity - as desirable to both average Torontonians and the knowledge economy workers the City sought to attract. The 2002 official plan described arts, culture, and heritage as central components of Toronto's intensification; and the Culture Plan responded in turn with a push to include cultural planning goals alongside other planning activities.

The City's enthusiasm for creative cities was further demonstrated by Mayor David Miller's Agenda for Prosperity (Toronto Mayor's Economic Competitiveness Advisory Committee, 2008), which held a central role for culture and creativity. Throughout Miller's mayoralty, civic enthusiasm for arts and culture was strategically channelled in an attempt to define Toronto as the Cultural Capital of Canada (Bain, 2013). The cultural economy has featured prominently in tools produced to support 
cultural planning. The Cultural Location Index (CLI), developed for the City by the Martin Prosperity Institute, attempts to visualise the intersection of culture, economy, and place by measuring census tracts where the cultural workforce lives and works, as well as where there are high concentrations of cultural facilities. Its key revelation was the significant distribution of cultural activity across the city, highlighting that there are no "cultural deserts" in Toronto (Martin Prosperity Institute et al, 2011, p. 55).

The City of Toronto's Culture Division operates within the same department as economic development. At the provincial level, culture is similarly positioned in the same ministry as tourism and sport. McDonough and Wekerle (2011) argue this arrangement enables cities to use culture and cultural planning to create economic returns, which subsequently supports community development goals. This instrumental approach may explain the longevity of culture as part of the urban policy agenda despite the rise of austerity and neoliberalism (Kloosterman, 2014). The language of economic development is prevalent throughout Toronto's current in-force cultural planning strategy, Creative Capital Gains: An Action Plan for Toronto. Creative Capital Gains (Creative Capital Advisory Council, 2011) was unanimously adopted by City Council in May, 2011. Its primary policy message was the need to meet the $\$ 25$ per capita arts funding target introduced by the 2003 plan. The action plan also stresses that the City must address the inadequate provision of affordable and sustainable space for cultural activity, correct for the inequitable distribution of cultural infrastructure to all areas of the city, ensure access and opportunity for all citizens to participate in cultural activities, invest in state-of-good-repair improvements for heritage properties that house cultural groups, and support the development of creative clusters and cultural scenes. Published at a time of significant political tension, Creative Capital Gains makes it clear that the private sector has a role to play supporting growth in the creative sector.

The Culture Plan for the Creative City is a comprehensive policy document that can inform non-profit arts, culture, and heritage activity; whereas Creative Capital Gains offers more targeted guidance to culture planners, and contains just over half the number of recommendations found in its 2003 counterpart. At present, Culture Division staff reports exclusively reference Creative Capital Gains and pursue the action items laid out in that strategy (S. Han, personal communication, November 3, 2015). 
Like all planning strategies, the culture plans implement the vision for Toronto articulated in the official plan. Toronto's in-force official plan (2015) envisions a future for Toronto where arts and culture are actively promoted, and cultural facilities are used to celebrate the best of life in the city. Chapter 3.5.2 addresses cultural planning, citing the role that arts and culture play in attracting and retaining residents, enriching quality of life, and supporting the local economy. Its policies include the promotion and support of a wide range of arts and cultural activities, both community-based and commercial; access for the arts and culture sector to City owned facilities; the promotion of new notfor-profit facilities using development incentives and public initiatives; engaging artists in local beautification projects; and the creation and promotion of arts districts and corridors for both tourism and revitalisation efforts. The official plan also recognises that Toronto is a regional focal point; as such, municipal support for culture and entertainment is a service for both the residents of Toronto and the broader population of the Greater Toronto Area. Likewise, culture sector workers and advocates often borrow the language of ecology to describe the multiplicity of inputs, outputs, and stakeholders that directly or indirectly engage with the sector. An ecological approach emphasises relationships and considers how careers, ideas, money, products, content, creators, and consumers all interact in a system comprised of commercial, not-for-profit, academic, and community-based activity (Holden, 2015). As such, the impact of developments or investment in the culture sector may be much more significant than what is immediately quantifiable.

Creative city discourse intends for cultural planning to influence and inform planning policy, including official plans and zoning by-laws (Kovacs, 2011). The PPS similarly advocates for a coordinated, integrated, and comprehensive approach to planning; while the Culture Plan encourages greater collaboration between the culture and planning departments. In practice, such integration has proved difficult to implement (Millward, 2013) often leaving cultural concerns marginalised and poorly integrated with other disciplines (Kovacs, 2011). Research by McDonough and Wekerle (2011) discovered that the fragmented municipal structure in Toronto limits cooperation between cultural and land use planners, and may require planners with limited expertise on culture step in to manage the priorities of the sector. Further, the authors argue that 
planning regulations provide limited tools to address cultural planning goals. Bain (2013) similarly observes there is a fragmented relationship between cultural policies at the municipal, provincial and federal levels. The author argues that this disconnect overburdens municipal governments with the cost of operating and maintaining cultural infrastructure, which has resulted in a large number of cultural properties in need of significant capital repairs. That said, cultural planners in Toronto currently benefit from political support and enthusiasm for the culture sector. In 2013 Toronto Council unanimously approved a direct investment of \$22.5 million that will bring the City's arts and culture funding level to $\$ 25$ per capita by 2017 and finally realize the funding target set in the 2003 culture plan (Toronto Arts Council, 2013a). A key priority for this funding is support for youth and diverse communities in Toronto's inner suburbs (TAC, 2013b). The City has also embarked upon the highly publicized Austin-Toronto Music City Alliance, which seeks to rebrand Toronto as a "music-centric" destination and attract investment, tourism, and new industry (City of Toronto, 2013a).

Political support for culture is owed in no small part to concerted advocacy and outreach efforts on the part of Toronto's cultural community ${ }^{1}$. As evidence, the 2013 arts funding announcement included congratulations from a City Councillor for "all the hard work by the passionate, dedicated people" who had been involved in the process; while the Toronto Arts Council (TAC) gave credit to the young artists and activists who successfully argued for a tax on billboards to support the arts sector (TAC, 2013a). Similarly, the TAC website offers a timeline for the funding increase that begins in 2001 with the formation of Beautiful City, the movement that advocated for the billboard tax for over a decade. That timeline is punctuated by major advocacy efforts like the Friends of the Arts Coalition, which formed in 2011 to show public support for the arts when the City was considering a $10 \%$ cut to arts funding (TAC, n.d.).

Arts advocacy takes place year-round in Toronto and Canada. Granting agencies like the TAC, as well as arts service organisations like the Toronto Alliance for the Performing Arts and the Professional Association of Canadian Theatres, have volunteer

\footnotetext{
${ }^{1}$ The author of this paper has been an active participant in Toronto-based arts advocacy. She has been a member of the Advocacy Committee of the Toronto Alliance for the Performing Arts since 2011, which participated in the Friends of the Arts movement. In 2014, the author co-chaired the 2014 ArtsVote campaign.
} 
advocacy committees that outreach to government stakeholders and produce toolkits to empower community members to do the same. Sector advocacy regularly coalesces under the ArtsVote banner - a grassroots initiative undertaken by groups across Canada and the United States to highlight the importance of arts and culture during election campaigns and mobilise voters to elect arts-friendly candidates. Importantly, the majority of sector advocacy in Canada is conducted on a volunteer basis. The Canada Revenue Agency restricts charities from dedicating more than $10 \%$ of their resources to "allowable political activity," which is often poorly defined, subject arbitrary interpretation, and can be used to threaten the ongoing operations of an arts group on ideological grounds (Stolk, 2016). As such, culture sector workers and supporters are often required to dedicate a tremendous amount of unpaid and unaffiliated energy toward government relations.

\subsection{The Intersection of Section 37 and Cultural Planning in Toronto}

Importantly, both Creative Capital Gains and the Culture Plan for the Creative City acknowledge that the property tax offers limited opportunities to increase culture funding. The Development Charges Act does not consider cultural facilities an eligible service to be paid for through a charge (Development Charges Act, 1997), regardless of the increased need for cultural services that the new development might generate. As such, a series of revenue-oriented policies are offered in Toronto's culture plans to further the interests of the culture sector without placing demands on the City's operating budget. Both documents recommend leveraging s. 37 agreements to realise cultural benefits.

Toronto's official plan uses general terms to outline the cultural benefits eligible for consideration in s. 37 agreements. Chapter 5.1.1, Policy 6 names only public art and other non-profit arts and cultural facilities, leaving a great deal of flexibility with respect to the form these benefits might take. Consequently, Creative Capital Gains advocates for clear communication with City Councillors to ensure they understand and can respond to the cultural infrastructure needs in their wards. These recommendations have been met with enthusiasm by culture sector advocates. For some, s. 37 agreements are an opportunity to mitigate the disruptive potential of high land values and rapid intensification by channeling these phenomena toward creative vitality 
(Sandals, 2013). To the City's Culture Division, s.37 is "a catalytic tool for cultural infrastructure development" (Toronto, 2014a, p. 2) that has been actively promoted in consultations with the public and the culture sector.

Prior to the City-wide review of s. 37 agreements in 2014, a report was produced by R.E. Millward and Associates for Toronto Culture Division that explores the specific application of s. 37 for securing cultural benefits. Chief among the strengths of s. 37 funding identified by the report is that it serves as a "complementary and alternative revenue stream" (Millward, 2013, p. 4) for a sector with limited financial means. Furthermore, there is little risk that s. 37 funding will be rescinded once agreed upon; unlike other funding sources, these agreements are registered in by-laws that can only be amended through a formal process. However, the report stresses that s. 37 agreements may not be appropriate or effective solutions for all cultural planning goals. Agreements are tied to large-scale developments, which are typically located downtown or along major transit corridors. As such, there is limited opportunity to use s. 37 agreements to support cultural infrastructure projects in Toronto's inner suburbs and low density areas. The Millward report also emphasises that s. 37 is not a panacea: the funding is limited to capital facilities and cannot meet the needs of the culture sector with respect to operating funds, programming, or staffing requirements.

In order for s. 37 agreements to be a more effective tool for cultural planning, greater integration of Culture Division staff in rezoning and development review is essential (Millward, 2013). At present, no mechanism exists that requires culture be a consideration in s. 37 negotiations (McDonough and Wekerle, 2011). In practice, few departments receive notice of a development proposal and as such there is limited opportunity for priorities generated outside of City Planning to be represented in s. 37 agreements (Moore, 2013b).

Of particular note are the limits of s. 37 agreements as a tool to expand Toronto's cultural footprint in underserviced inner suburbs. S. 37 agreements have been criticised on the grounds that they offer little redistributive value, concentrating benefits in the downtown core and along existing transit corridors (Moore, 2013b). The Millward report recommends that the City locate cultural facilities at nodes to ensure these amenities are both accessible to larger populations and proximate to the types of developments 
that could generate s. 37 funding. Pre-identifying possible centres that can serve Neighbourhoods, Apartment Neighbourhoods, and Avenues is further recommended as an opportunity to support new arts districts throughout Toronto. Finally, the report acknowledges that timing, space requirements, and partnership opportunities often determine and constrain where cultural facilities are able to locate. As such, the Millward report recommends that planners and councillors expand the geographic boundary they consider when negotiating s. 37 benefits.

These challenges suggest s. 37 policies ought to be rethought in the context of cultural benefits. The catchment area for a new cultural facility may extend well beyond the development that funds it, particularly if that facility is established in an underserviced neighbourhood or ward. This not only complicates the traditional understanding of the geographic nexus, but also raises the possibility that multiple councillors ought to be involved in the negotiation in order to best represent the catchment base. Similarly, new cultural infrastructure may serve not only the local community, but also culture sector workers from across Toronto, and potentially a wider range of cultural consumers throughout the GTA. The OP acknowledges that culture and entertainment serve both local and regional populations. As such, neighbourhood or ward level analyses of community need may not accurately reflect the purpose of a new cultural facility.

\subsection{Study Directions}

Although Toronto's Culture Division has recognised the value of s. 37 for over a decade and has promoted its "catalytic" potential, the preceding literature review reveals a series of tensions that emerge at the intersection of s. 37 and cultural planning.

Despite OMB decisions, both the MMAH and cultural planning documents present s. 37 as a revenue generating mechanism outside the property tax. Creative Capital Gains similarly stresses that the private sector has a responsibility to supplement municipal investment in the culture sector; indeed, the proportion of total revenues generated by performing arts organisations from the private sector is almost on par with public funding contributions (Business for the Arts, 2011). The implications of diffuse funding responsibilities for cultural infrastructure are unclear. In particular, the 
issue calls into question how instrumental s. 37 funding is relative to all other financing tools required to realise cultural amenities.

Similarly, despite the requirement that developments qualify as good planning prior to the provision of $\mathrm{s.} 37$ benefits, the literature underscores a compensatory relationship between s. 37 benefits and development impacts. There is an inherent contradiction between the good planning requirement and the responsibilities assumed by municipal cultural planners: a primary reason to invest in culture - whether through grants, loans, or the provision of space - is to correct against the market's failure to provide public goods like art and culture. In Toronto, planning decisions - including "good" planning decisions - are one of the factors that have driven up the cost of land, the demand for development, and the scarcity of space for non-commercial community activities. This tension highlights the need to better understand the planning context in which s. 37 was used to secure cultural benefits and the relationship the agreements had to the needs of the culture sector. This is particularly true given accusations that the agreement terms are not always tied to a clear planning rationale.

Research by R.E. Millward and Associates has already identified opportunities to improve the use of s. 37 as a mechanism to secure cultural amenities. This report was developed for the City and as such its focus is on municipal policy and recommendations for planners. There is opportunity to complement this study with further research on the experiences of the cultural groups that steward these new community benefits. Similarly, although there are indications that cultural amenities represent only a small percentage of community benefits secured through s. 37 agreements (Millward, 2013; Moore, 2013a, 2013b), no studies quantify these benefits or their distribution throughout the City. As such, it is not yet possible to offer an empirical evaluation of how effective s. 37 has been at securing cultural benefits in Toronto.

The goal of this research project is to investigate how instrumental s. 37 agreements have been to the provision of spaces for cultural production and dissemination in the City of Toronto. To do so we shall analyse what benefits have been secured through these agreements, as well as where and in what context. For a strategic selection of performing arts facilities we shall consider the experiences of 
cultural organisations that embarked upon these projects, and how s. 37 figured as part of the larger capital campaigns, in order to better understand who and what is relied upon to build new cultural spaces. Performing arts facilities serve as an especially revealing research topic because they pose significant capital demands compared to the requirements of other art forms. Finally, the paper will consider the implications of these findings as the City of Toronto and the culture sector attempt to realise the visions set out in the 2003 and 2011 culture plans, with particular consideration for the inequitable distribution of cultural resources in underserviced areas outside of the downtown core. 


\subsection{Methods}

This project employed a mixed methods approach to explore the research questions. The first phase the project involved quantitative analysis of the use of s. 37 agreements in the City of Toronto to measure and visualise the distribution of cultural amenities. A database of agreements and benefits was developed based on a matrix created by Jeff Biggar, PhD candidate at the University of Toronto (Biggar and City of Toronto, 2014). The list of agreements in the matrix was cross referenced and enhanced using a more recent list published by the City of Toronto (Toronto, 2014b). Twenty one records were excluded from the dataset based on comments from the City indicating the agreement was not executed, the development had not gone forward, or the benefits had been secured under a different section of the Planning Act.

Mr. Biggar's coding structure was also used as the basis for quantitative analysis. He identifies nine types of benefits secured using s. 37 agreements:

- Heritage

- Affordable Housing

- Public Art

- Community / Culture / Recreation

- Libraries

- Roads / Streetscapes

- Parks

- Transit

- Other

For the purpose of this project, the Community / Culture / Recreation category was further subdivided to highlight different kinds of cultural benefits:

- Artist Affordable Housing

- New Art / Cultural Space

- Upgrades to Existing Spaces

Some amenities in the New Art / Cultural Spaces category were double coded as New Performing Arts Spaces to help identify appropriate facilities for case study research. These four categories, as well as Public Art and Libraries, were also coded in a general Arts / Culture category to visualise how arts and culture benefits factor as a percentage of all benefits secured.

Finally, GIS software was used to map the locations of all the developments that contributed arts and culture benefits. This project is primarily concerned with the 
provision of spaces for artists, as well as arts production and dissemination. As such, the locations of developments that contributed to public art were excluded from the mapping exercise. Asset mapping is regularly undertaken by cultural planners (Grodach, 2013; Kovacs, 2011), however the exercise is especially important in the Toronto context. Hulchanski's (2010) formative research on the geography of poverty, ethnicity, and inequality in Toronto underscores the ethical imperative to analyse the distribution of public assets. Mapping helps to illustrate where gaps in service provision may exacerbate inequalities and burden already vulnerable communities.

Through GIS mapping, two performing arts facilities were identified for further qualitative and quantitative analysis to develop a richer understanding of how cultural organisations have engaged with s. 37 agreements. The Theatre Centre in Ward 18 and Artscape Sandbox in Ward 20 were selected because they are located in different parts of the city, are run by different arts organizations, and represent purpose-built performing arts spaces. Qualitative content analysis of zoning by-laws and staff reports was conducted for each performing arts development to better understand the planning context in which s. 37 was employed. An inductive approach was used: observation and data analysis occurred before the generalisations and conclusions were made. Similarly, this phase employed conventional content analysis, such that observation was the first part of the process and coding took place during the analysis based on the contents of the data (Neuman \& Robson, 2012).

Plans, policies, and by-laws do not articulate the influence of key decisionmakers or events that occurred during policy-development, nor do they summarise the experiences of individual stakeholders (Grodach, 2013). As such, semi-structured qualitative interviews were undertaken with key stakeholders from the performing arts facilities and/or the developers that provided the community benefits. An open coding approach inspired by Alison L. Bain (2003) was employed for content analysis and to synthesise findings from interviews. This strategy supports an inductive approach by allowing themes and meanings to emerge organically during analysis. Finally, the interviews were supplemented by a brief financial survey completed by representatives from the performing arts facilities. The surveys explored the value of s. 37 contributions relative to other funding sources in the facilities' capital budgets. The surveys helped to 
determine how instrumental the agreements were in the provision of new cultural infrastructure.

Crow's Theatre, a third performing arts facility built using s. 37 funding, was also identified as a possible case study. However, due to time and resource constraints, neither Crow's Theatre nor the developer they worked with could participate in the research study. The case study was consequently excluded from the project.

\subsection{Research Limitations}

There are a number of research limitations inherent in these methods. The contents of the s. 37 database were developed using summaries published by the City of Toronto, as it is beyond the scope of this master's project to secure original copies of the agreements. As such, the database does not correct for possible record keeping errors or omissions on the part of the City, and may contain interpretation errors made by the researcher. The database reflects all benefits named in the agreement summaries and fails to distinguish between what was negotiated through s. 37 and what was included in the s. 37 by-law as a legal convenience. Similarly, the database analysis reflects only what is named in the by-laws that implement the s. 37 agreements. It is beyond the scope of this project to confirm which benefits were actually realised, particularly in cases where an "and/or" benefit scenario was named. The coding also does not distinguish between artist housing and artist live/work units, which serve as art-making spaces and may be accessible to the public for exhibition and sales activities.

The benefits coded as arts and culture spaces that are neither libraries nor performing arts facilities predominantly consist of exhibition spaces like museums, archives, and galleries. This project considers purpose-built cultural spaces, and as such community centres that may support professional or community-based art practices were not considered. Similarly, some readers may object to the exclusion of parks and heritage benefits from the list of cultural benefits secured. Indeed, cultural planning literature sometimes employs a much broader definition of cultural amenities, including facilities like zoos and sports arenas (Kloosterman, 2014). Throughout policy and practice the definition of culture is interpreted subjectively (Kovacs, 2011). As such, similar studies investigating cultural benefits may yield different results. 


\subsection{Research Findings}

The following discussion presents the results of the research methods in three sections. First, quantitative analysis and asset mapping are used to measure the occurrence rates and distribution of cultural benefits throughout the City of Toronto. Next, the report presents case study research that explores the two selected performing arts facilities. Content analysis is used to provide an overview of the planning context for each development. The results of the interviews and financial surveys demonstrate how the s. 37 agreement occurred and how instrumental the funding was to the success of the capital project. The section concludes with a discussion of the themes that emerge from both qualitative and quantitative analysis.

\section{S. 37 CULTURAL BENEFITS CASE STUDY RESEARCH}

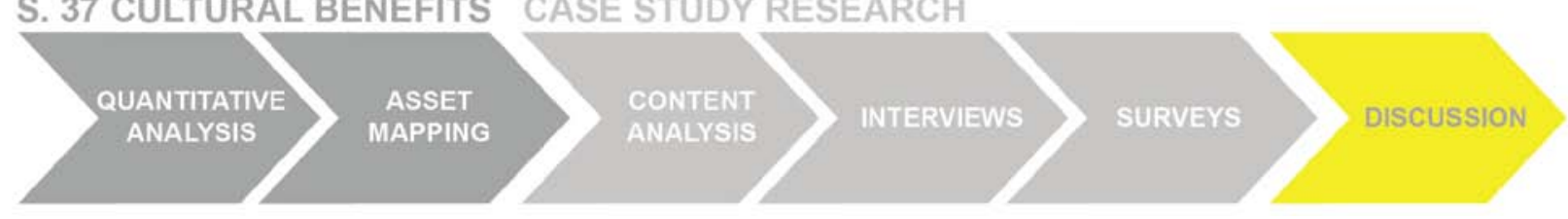

Figure 1: Research findings

\subsection{Cultural Benefits Secured}

\subsubsection{Occurrences of Benefit Types}

The database developed for this project comprises 633 density bonus agreements dating from 1984 to 2014. Most agreements name more than one type of benefit, including benefits secured as a matter of legal convenience:

\begin{tabular}{|l|c|}
\hline Table 1. Type of benefft secured & $\begin{array}{c}\text { Occurrence rate } \\
\text { (as a proportion of all } \\
\text { benefits secured) }\end{array}$ \\
\hline $\begin{array}{l}\text { Heritage } \\
\text { Includes preservation, restoration, and/or commemoration of heritage resources. }\end{array}$ & $18.96 \%$ \\
\hline $\begin{array}{l}\text { Affordable Housing } \\
\text { Includes affordable housing based on either cost of unit or size of unit, creation or retention of } \\
\text { rental units, tenant relocation plans, and housing for vulnerable groups such as seniors. } \\
\text { Excludes affordable artist housing. }\end{array}$ & $31.44 \%$ \\
\hline $\begin{array}{l}\text { Community I Recreation } \\
\text { Includes indoor amenity spaces in new developments. }\end{array}$ & $45.81 \%$ \\
\hline $\begin{array}{l}\text { Roads I Streetscapes } \\
\text { Includes pedestrian pathways and tunnels, as well as general contributions to the public realm. }\end{array}$ & \\
\hline $\begin{array}{l}\text { Parks } \\
\text { Includes publicly accessible private spaces and other outdoor spaces in new developments. }\end{array}$ & $55.92 \%$ \\
\hline
\end{tabular}




\begin{tabular}{|l|c|}
\hline $\begin{array}{l}\text { Transit } \\
\text { Includes improved access to transit stations. }\end{array}$ & $6.79 \%$ \\
\hline $\begin{array}{l}\text { Arts and Culture } \\
\text { Includes all subcategories of arts and culture. }\end{array}$ & $38.07 \%$ \\
\hline $\begin{array}{l}\text { Other } \\
\text { Includes writing and/or conforming to studies, excluding heritage studies; metropasses and other } \\
\text { benefits to new residents; improved materials and other capital upgrades to the development; } \\
\text { and unspecified capital improvements in the area of the development. }\end{array}$ & $44.71 \%$ \\
\hline
\end{tabular}

Although arts and culture are fairly well represented among all benefits named in S. 37 agreements, the range of benefits within the arts and culture category is not evenly distributed:

\begin{tabular}{|l|c|}
\hline Table 2: Type of arts and culture benefit secured & $\begin{array}{c}\text { Occurrence rate } \\
\text { (as a proportion of all } \\
\text { benefits secured) }\end{array}$ \\
\hline Public Art & $30.96 \%$ \\
\hline $\begin{array}{l}\text { Affordable Artist Housing } \\
\text { Includes both residential and live/work units. }\end{array}$ & $1.74 \%$ \\
\hline $\begin{array}{l}\text { New Art / Cultural Space } \\
\text { Includes performing arts spaces, galleries, cinemas, museums, archives, and other unspecified } \\
\text { ccultural" spaces. Excludes live/work units that may be used for art production and/or } \\
\text { dissemination. }\end{array}$ & $5.21 \%$ \\
\hline $\begin{array}{l}\text { New Performing Arts Space } \\
\text { Upgrades to Existing Arts / Cultural Space } \\
\text { Includes one lease extension }\end{array}$ & $1.58 \%$ \\
\hline $\begin{array}{l}\text { Libraries } \\
\text { Includes new libraries and improvements to existing facilities. }\end{array}$ & $2.21 \%$ \\
\hline
\end{tabular}

Capital intensive and subsidised activities like production space and housing do not feature prominently in the list of benefits named in s. 37 agreements. From a purely quantitative perspective, these figures suggest that s. 37 agreements have made limited contributions to the growth of the culture sector beyond the provision of visual amenities. However, the impact of the facilities secured may be more substantive than their low occurrence rate suggests. A single theatre, gallery, or library may host the work of hundreds of artists in the course of a year. It is beyond the scope of this project to investigate the role of each cultural amenity in the wider culture sector ecology. As such, though the use of s. 37 agreements to secure space for cultural production and dissemination is infrequent compared to the other ways s. 37 has been mobilised, a 
qualitative investigation is required to generate a more meaningful understanding of the impact of this planning tool and its capacity to support cultural infrastructure development.

\subsubsection{Distribution of Benefits}

To establish a clear picture of where and how s. 37 has been used, the location of developments that name cultural benefits have been mapped alongside the location of cultural facilities recognised by the City's Culture Division. Instances of public art as a cultural benefit have been excluded from the mapping exercise.

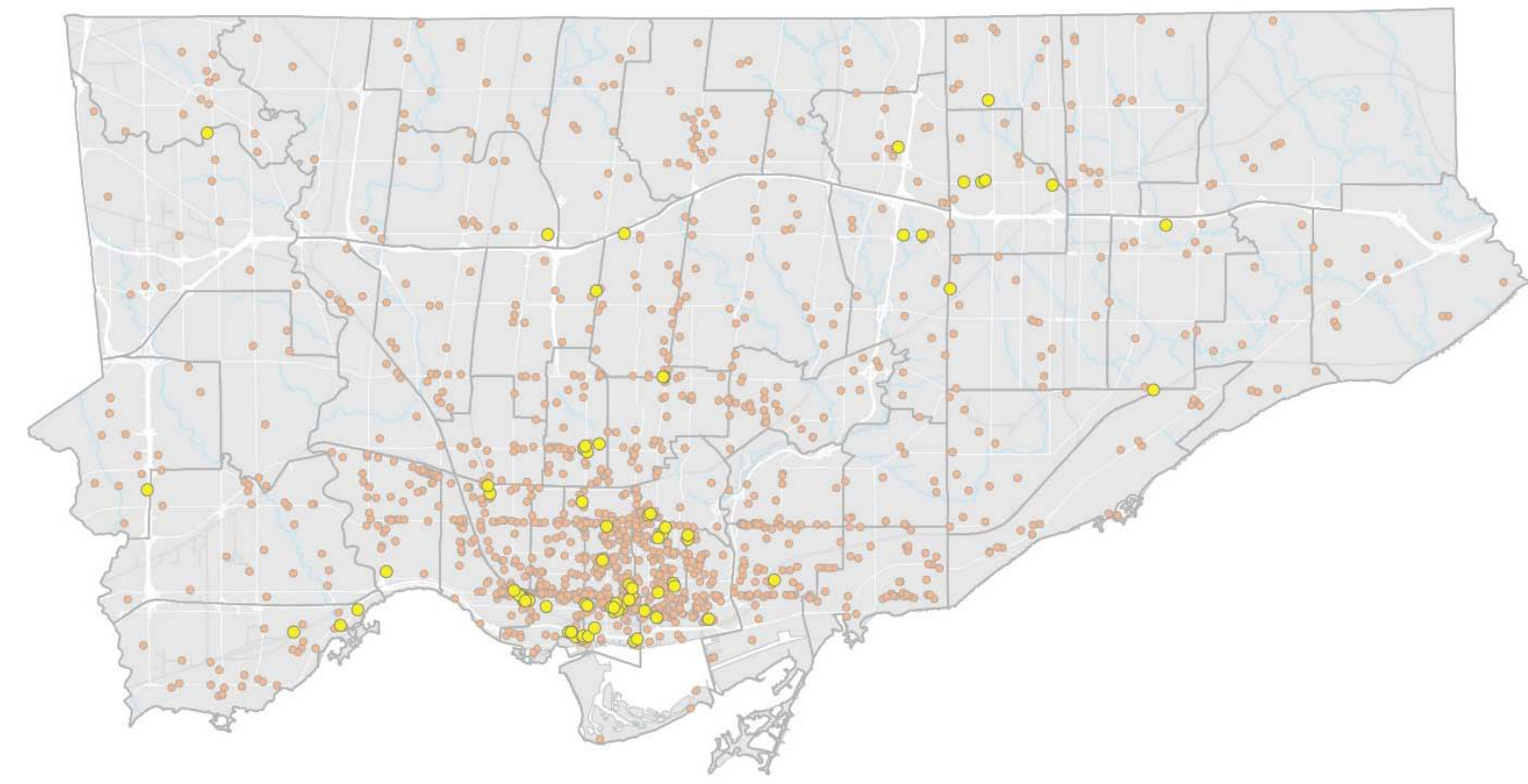

- Location of development where cultural amenities were named in Section 37 agreement

- Cultural facility identified by Making Space for Culture consultations

Figure 2: Section 37 agreements that name cultural benefits

S. 37 cultural benefits are not broadly distributed: the 80 developments that name cultural benefits are located in only 22 of Toronto's 44 wards. In fact, four wards Wards $18,19,20$, and 27 - contain an overwhelming $57.5 \%$ of the developments that name cultural benefits. Both cultural facilities and the developments that support cultural amenities tend to cluster downtown and on transit lines, as other writers have observed (Millward, 2013; Moore, 2013b). The synergy is logical: cultural activities benefit from dense urban environments that provide convenient access to both patrons and cultural 
networks; while tall and/or high density developments locate where the market, existing infrastructure, and neighbourhood context can support them. However, the unintended result of this pairing is an inequitable distribution of cultural amenities - and by extension cultural benefits - in areas of Toronto that are less dense and have less access to higher order transit. This distribution pattern is doubly problematic given these parts of Toronto are home to a disproportionate amount of Toronto's lower income, racialised, and immigrant populations (Hulchanski, 2010).

The distribution of cultural benefits is more problematic when the locations of developments are mapped based on the type of benefit named in the agreement:

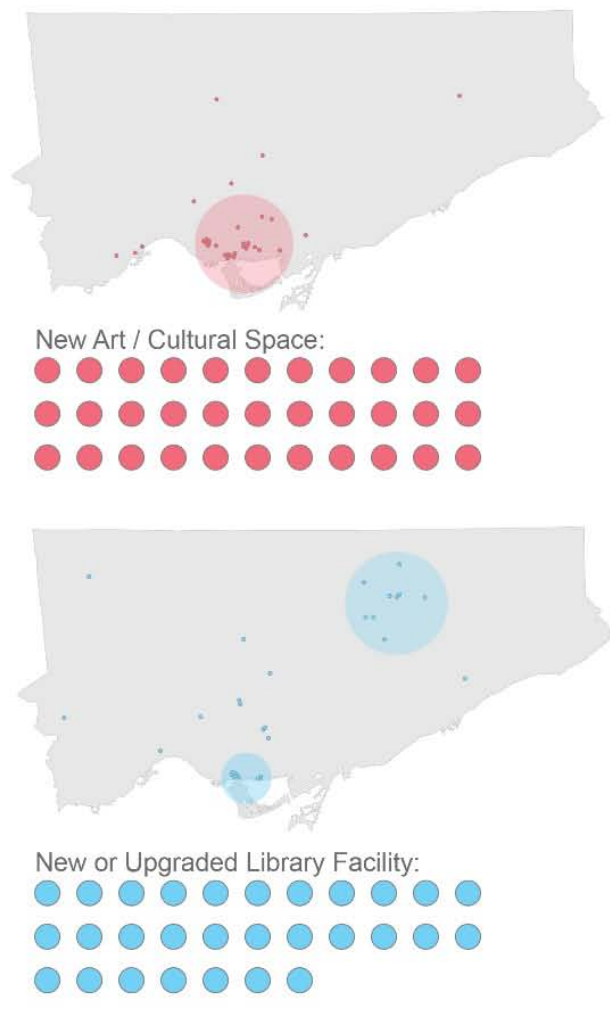

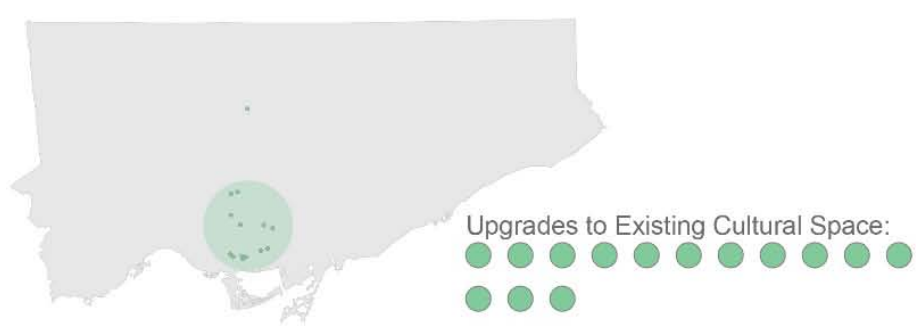

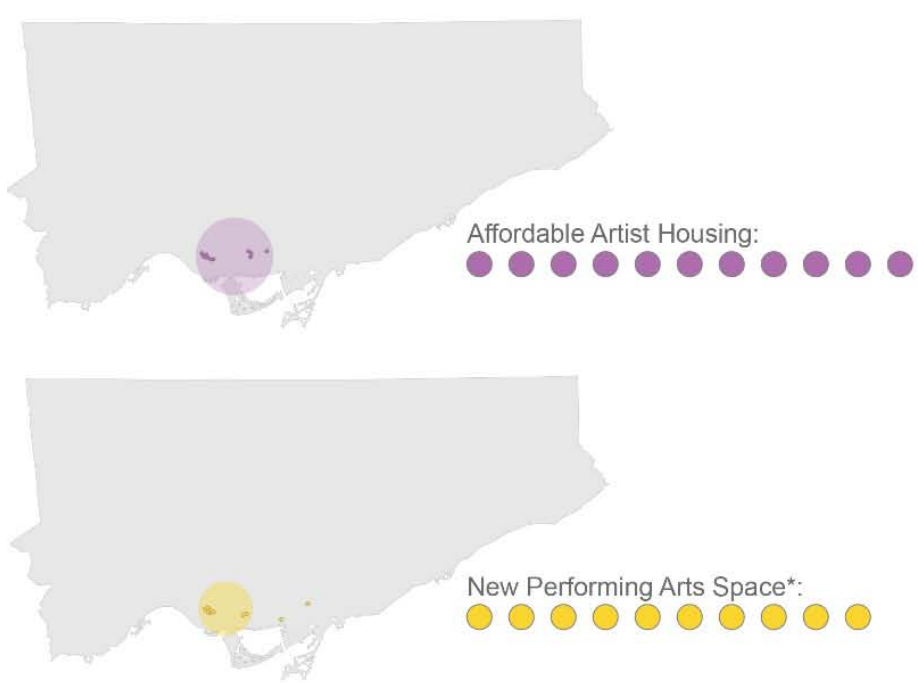

"These data points are also mapped as New Art / Cultural Space

Figure 3: Instances of benefits named in Section 37 agreements

Libraries have the broadest distribution throughout the city. This is unsurprising given Toronto Public Library is a City agency that all Councillors are aware of, making it an obvious recipient of funding support. The same level of visibility, and corresponding recognition of need, cannot be equally expected for other arts and culture organisations. It is perhaps for this reason that the benefits directed to new and upgraded cultural 
spaces, affordable artist housing, and new performing arts spaces are predominantly clustered in parts of the city where cultural facilities are more visible and a legacy of cultural production is more recognised.

\subsubsection{Identifying Possible Case Studies}

The 80 cultural benefits named or identifiable from the s. 37 database were cross referenced against the findings of the City's Making Space for Culture (MSFC) consultations. MSFC identifies five of these benefits as performance spaces: the Downsview Collegiate community arts facilities, the Theatre Centre, Artscape Youngplace, Artscape Wychwood Barns, and the Artscape Distillery Studios. Two additional performing arts benefits were constructed or planned after the MSFC consultations: Artscape Sandbox and Crow's Theatre.

The new facilities constructed for Crow's Theatre and the Theatre Centre emerged as comparable case studies. Both organisations are professional not-for-profit arts companies with a performing arts focus, and their new venues have similar sizes and technical capabilities. The facilities are also located in different wards, offering an opportunity to compare diverse planning contexts. Conversely, Artscape Youngplace was excluded because the building does not include a formal theatre space of a comparable scale or technical capability. Downsview was excluded on the basis that it is geared to community arts $^{2}$ rather than professional arts, which similarly suggests the venue size, technical capability, and intended use would not be comparable. Although three Artscape properties qualified as prospective case studies, only one property was selected for this project given there is limited value in multiple explorations of the same not-for-profit organisation. Studying more than one Artscape properties could bias the results toward that organisation's experience. Artscape Sandbox was selected for this project because it is Artscape's newest, and therefore least studied, property in the city.

\footnotetext{
${ }^{2}$ Community arts play a vital role in Toronto's cultural ecology, and this exclusion is not intended to privilege professional arts over community-based practices. The Toronto Arts Council definition of community arts emphasises art practice in which professional artists and community members collaborate to create feelings of inclusion, understanding, and self-expression (C. Eastcott, personal communication, November 6, 2015). That the Downsview space was created for such a practice, and is further located within a school building, suggests there is limited opportunity to compare the venue or the community needs recognised through the s. 37 agreement against professional arts case studies.
} 
Although it has a larger footprint, the Sandbox facilities are geared toward the same small to mid-sized companies as the Theatre Centre and Crow's Theatre.

\subsection{Case Studies}

Case study research was pursued for the Theatre Centre and Artscape Sandbox, while Crow's Theatre declined to participate in the project. The case studies begin with an overview of the arts companies and their relevant partners, followed by an analysis of the planning context in which the s. 37 agreements occurred. Next, the narrative shifts to explore the experiences of the arts companies and the events that led to the s. 37 agreement. Finally, the value of the s. 37 agreement is considered as part of the overall capital budget. The analysis seeks to answer two primary questions: how instrumental was s. 37 funding to the capital budget, and can it be considered a catalyst for these cultural infrastructure developments?

\subsubsection{The Theatre Centre}

"What I love about the new Theatre Centre is that it brings dignity to the questions that are being asked within."

Brendan Healy (@Brendan_Healy); past artistic director, Buddies in Bad Times Theatre

The Theatre Centre is a live-arts incubator with a mandate to nurture, invest in, and champion artists and their work. The company acts as a research and development hub for new art by providing space, funding, and mentorship opportunities to artists and companies whose work is experimental, alternative, and challenges traditional definitions of theatre (Theatre Centre, n.d.a). In March 2014, the Theatre Centre opened its first permanent home at Queen Street West and Lisgar Street in Toronto's west end. The venue, a designated heritage property, is a former Carnegie Library building that housed the Queen Lisgar Branch until 1964. Prior to its renovation, this property provided office space for the Parkdale branch of Toronto Public Health (Theatre Centre, n.d.b). The space now contains a 200-220 seat theatre in the former library reading room, a smaller black box space, a lobby and hallways designed to accommodate smaller performances or installations, and a cafe and meeting space that is open to the public (Maga, 2014). 


\subsubsection{Planning Context}

The new venue for the Theatre Centre was one element in the larger redevelopment of an area known as the West Queen West Triangle (WQWT) in Toronto's west end. The WQWT is a designated Regeneration Area in Toronto's official plan and located within the boundaries of the Garrison Common North Secondary Plan. A Regeneration Area designation is intended to help attract new investment to an area and support its revitalisation by animating streets, enabling a diverse mix of uses, and repurposing heritage buildings (Toronto, 2010). The regeneration of the WQWT and its impact on the local arts community is well-documented by McDonough and Wekerle (2011). From 2005-2006, multiple development applications were submitted to transform the former industrial tract. These applications did not acknowledge the area's cultural assets, nor the fact that the WQWT was home to many artists and creative businesses who relied upon the existing built form. The authors are critical of the subsequent decisions by the $\mathrm{OMB}$ and the City for not going far enough for to protect these cultural interests. The redevelopment did lead to a series of cultural amenities and guarantees to the community, including policies to ensure there would be no net loss of non-residential space for creative activity. However, when the applications were submitted in 2005, the City ultimately found itself responding to sudden development pressures in the WQWT that it had not anticipated (L. Martin, personal communication, March 4, 2016).

Content analysis of relevant official and secondary plan policies, staff reports, and by-laws supports the argument that there was disconnect between land use planning tools and cultural development goals in the WQWT. Notably, the current iteration of the Garrison Common North Secondary Plan makes no references to arts or cultural uses in either the WQWT area policies or the overall vision for the secondary plan area. S. 37 benefits are only referenced in regard to general community services and facilities (Toronto, n.d). Development in Regeneration Areas is meant to be guided by frameworks set out in secondary plans (Toronto, 2010), which can similarly be employed to target specific community benefits for $\mathrm{s}$. 37 funding and pool resources

from multiple agreements to support larger projects (Millward, 2013). A 2007 staff report outlining a proposed OPA would have set out a vision for the WQWT where "the use of 
lands for arts and cultural facilities and other creative industries will be encouraged" (Toronto, 2007b, p. 24). Although this could have been a proactive mechanism for planners to direct s. 37 funding toward cultural benefits, it was not in place when the WQWT was facing development pressures and it has not been integrated into the secondary plan that is currently available on the City of Toronto website.

Six developments contributed support for the renovation of the Carnegie Library through s. 37 agreements. Two of these agreements also contained provisions to help relocate the Toronto Public Health offices to a new space in the area. Given that each agreement lists a number of benefits, it is impossible to determine from by-laws alone how much s. 37 funding was directed to the Theatre Centre. By-laws for these developments contain consistent provisions permitting a range of arts and culture uses that are subject to exceptions like reduced parking requirements. Live / work units for artists are able to contribute toward the developments' non-residential gross floor area requirement. The by-laws also appear to direct arts activity to broader policy goals. For instance, provisions to ensure an animated streetscape, such as smaller retail floor prints and building massed close to the property line, are supported by provisions that permit artistic and cultural uses at-grade. Certain by-laws and staff reports acknowledge the arts employment cluster in the area. Notably, a 2007 staff report states that benefits secured through s. 37 agreements will be used to mitigate against the impact of redevelopment. The renovation of the Carnegie Library is one of the facilities recommended by City Planning for s. 37 support.

\subsubsection{How the s. 37 Agreement Occurred}

The Theatre Centre became the recipient of s. 37 funding through a fortuitous combination of timing, need, and social networks. The company was not an obvious choice to steward community benefits: at the time the WQWT redevelopment was initiated, the Theatre Centre was largely invisible outside of the arts community. As an incubator and co-producer, the Theatre Centre brand was necessarily subordinate to the arts partners it nurtured. It also lacked the physical infrastructure to be a presence in the neighbourhood. At the time, the Theatre Centre was operating the basement black box space in the nearby Great Hall, where a new ownership arrangement had thrown their tenancy into question. The company was actively seeking a new venue when it 
learned then-City Councillor Adam Giambrone was exploring the potential to relocate the Toronto Public Health offices at 1115 Queen Street West to make space for an arts group. The Theatre Centre was able to strike up a relationship with the Councillor and his executive assistant to make their space needs known. As such, when it came time to negotiate the s. 37 agreements for the developments in the WQWT, a performance space helmed by the Theatre Centre in the former Carnegie Library had already been identified as a prospective community benefit (F. Boni, personal communication, February 10, 2016).

No single stakeholder brought forward the idea that s. 37 funding should be directed to the new Theatre Centre. Artistic and General Director Franco Boni gives credit to both the Councillor's office and the local community for the opportunity, however the range of arts and culture benefits secured from the WQWT developments can also be credited to the advocacy work of Active18. The community group formed in 2005 out of concern for the impact that the WQWT redevelopment would have on the neighbourhood's artistic community and assets. The timing happened to coincide with the Theatre Centre's tenancy issues at the Great Hall. Mr. Boni had received notice of Active18's first meeting to discuss development concerns, and attended in hopes of meeting new people and sharing the Theatre Centre's story. This event changed the course of the company's history: Mr. Boni joined the Active18 steering committee and the Theatre Centre became a visible player in the arts sector advocacy that would follow, further reinforcing the collective desire for a performing arts space as a community benefit.

Active18 was heavily involved in the planning process. The group hosted charrettes, attended planning meetings, and was even a signatory to the OMB cases. Although the result was broad support for the new Theatre Centre space, it required an incredible amount of social and intellectual capital in the form of donated professional time, the support of arts and planning influencers, fundraising, and volunteer time ( $F$. Boni, personal communication, February 10, 2016). The experiences of the Theatre Centre and Active18 reflect the significant amount of effort required of community groups to network with City Councillors and succeed in influencing the planning process. 
4.2.4 The Influence of s. 37

S. 37 funding comprises $16 \%$ of the Theatre Centre's $\$ 6.2 \mathrm{M}$ capital budget. Notably, the $\$ 1 \mathrm{M}$ contribution represents the entirety of the City funding allocated to the project. This supports the intent of the culture plans to mobilize s. 37 agreements as an alternative revenue stream for culture.

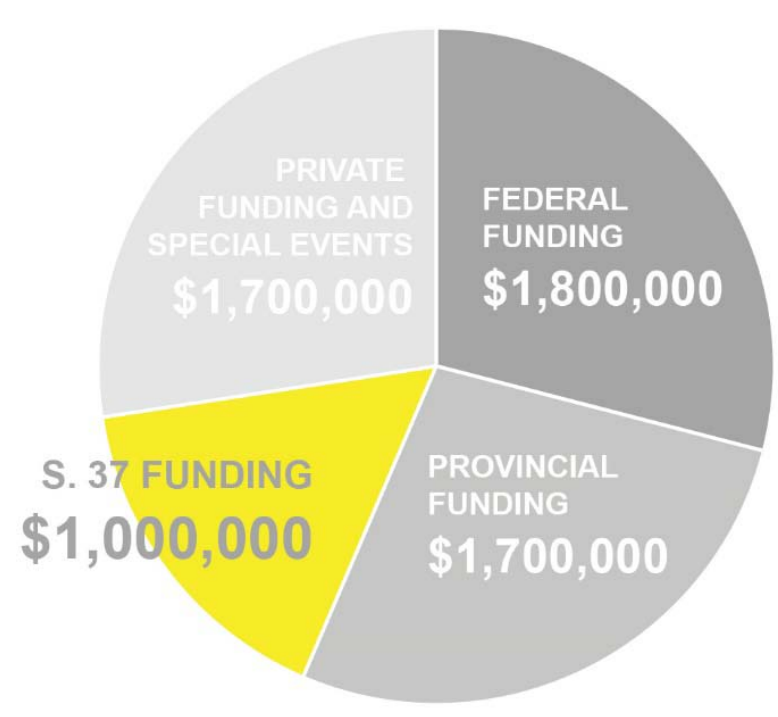

Figure 4: Theatre Centre capital budget

The $\$ 1 M$ contribution, announced by Councillor Giambrone in 2007, is considered a catalyst for the capital project and instrumental to realising the new performing arts space (F. Boni, personal communication, February 10, 2016). The funding was committed concurrent to Canadian Heritage funding for a feasibility study, which made it possible for the Theatre Centre to pursue other funding opportunities. Mr. Boni stresses that municipal support is critical before other levels of government can be approached for funding. This sentiment is echoed by research that has determined municipalities are often the first to invest in cultural initiatives. This demonstration of willingness and confidence on the part of local governments can be instrumental in enabling arts groups to leverage other public and private sector funding (Hill Strategies, 2012). Arriving at this commitment was not without its challenges: though it was never a struggle to convince stakeholders that a performing arts facility would be a valuable community benefit, the Theatre Centre and its supporters had to endure significant periods of uncertainty pursuing sometimes "elusive" s. 37 funding (F. Boni, personal communication, February 10, 2016). The ultimate victory was the result of constant advocacy and outreach to secure a commitment that could catalyse the larger campaign.

Yet the Theatre Centre story demonstrates that the catalytic effect of s. 37 and the planning process can extend beyond the capital facilities named in the agreements. The experience participating in the Active18 movement changed how the Theatre Centre conceives itself and the role it plays in the community: 
We're no longer about only serving the artists - although that's really important to us - but we've started to think about ourselves as a public space. That public space philosophy [is] influenced heavily by my involvement in planning, and understanding that this neighbourhood lacks public space...this process has affected me. It's changed the way I think about the building. (F. Boni, personal communication, February 10, 2016)

The venue now includes a publicly accessible common space with a cafe and free wifi. Its window wall opens in the summer, which allows the street and nearby Lisgar Park to merge with the venue and create a space for "public use, with cultural purpose" (Maga, 2014). While the process of securing a s. 37 agreement depended on timing, opportunity, as well as the power of relationship building and advocacy, the impact of these agreements is much more substantive than the provision of a single capital facility and can support much broader planning goals.

\subsubsection{Artscape Sandbox}

Artscape Sandbox is a multi-disciplinary performance and event space in Toronto's Entertainment District. The 6,000 square foot black box theatre runs on a social enterprise model with sliding rental rates designed to be affordable for not-forprofit organisations (Artscape, n.d.d). The Sandbox opened in September 2015 and is one of the newest properties developed by Artscape, a not-for-profit organisation that develops and manages cultural facilities and affordable artist housing in Toronto (Artscape, n.d.a).

The Sandbox is located in the podium of the Cinema Tower, a condominium property with commercial uses at street level that was developed by the Daniels Corporation. Artscape has a longstanding relationship with the Daniels Corporation through high-profile partnerships like the Daniels Spectrum, a community cultural hub operated by Artscape in Regent Park; and the upcoming Daniels Waterfront - City of the Arts development, where the Artscape Launchpad will act as an incubator, coworking facility, and entrepreneurship centre for arts organisations (Artscape, n.d.b, c). The Daniels Corporation is no stranger to arts-oriented projects; the company positions arts and culture integration as an important component of its approach to community 
building (Daniels Homes, n.d.). The Cinema Tower, for instance, is a follow-up to the nearby Festival Tower, a residential property built atop a podium that houses the Toronto International Film Festival (TIFF). Marketing for the Cinema Tower plays heavily on its proximity to the TIFF Bell Lightbox, as well as the arts and culture institutions that line the John Street Cultural Corridor (Urban Toronto, n.d.; Daniels Gateway, n.d.). For its part, the Daniels Corporation recognises a range of benefits to incorporating arts and culture into its developments. In addition to serving the company's broader city-building goals, arts and culture uses can make units more attractive to culture-savvy buyers. They also help ensure residential properties are active throughout the day by adding dynamic commercial and community-oriented activity to the site (N. Haggart, personal communication, March 3, 2016).

\subsubsection{Planning Context}

Artscape Sandbox is located in a Regeneration Area designated by Toronto's official plan and falls within the boundaries of the King-Spadina Secondary Plan. King and Spadina is a significant area in Toronto's planning history: along with King and Parliament, this area was rezoned in the 1990s to allow mixed uses, which supported then-Mayor Babara Hall's economic development plan to fast-track the conversion of former industrial buildings (Lehrer and Wieditz, 2009). The first iteration of the KingSpadina Secondary Plan was implemented in 1996 in response to the decline of the area's manufacturing industry. It sought to encourage reinvestment and housing development, while providing spaces for creative businesses. The secondary plan was supported by a community improvement plan (CIP), adopted in 1997, that focused on heritage, safety, and public space (Lintern, n.d.). The King-Spadina Secondary Plan was reviewed in 2005 to better understand the significant transformation the area had experienced and to address challenges like the proliferation of night clubs. The review also sought to preserve and enhance the area's historic built form character, and address service gaps in community facilities and the public realm. While acknowledging the area's entertainment uses, the review identifies John Street as a corridor that links significant cultural facilities despite being named one of the most inhospitable streets in the study area (The Planning Partnership, 2006). The City of Toronto is currently developing a streetscape design for John Street that will better reflect its role connecting 
iconic cultural institutions like the Art Gallery of Ontario, the TIFF Bell Lightbox, and the CBC's Toronto headquarters (City of Toronto, n.d.a).

Content analysis of the King-Spadina Secondary Plan and by-laws relevant to the Artscape Sandbox discovered limited references to arts and cultural activity. This seemingly contradicts the findings of the secondary plan review, which identifies a high number of entertainment and cultural facilities in the neighbourhood and argues these uses have had a profound impact on demographic trends (Planning Partnership, 2006). The secondary plan policies that explicitly relate to arts and culture uses are limited to the area policies for the Mirvish-Gehry development at King Street West and John Street. The plan prioritises s. 37 agreements for the provision of community services that achieve the CIP vision, as well as the conservation and maintenance of heritage buildings (City of Toronto, n.d.b). Although these priorities could indirectly support cultural activity, there is no direct reference in the CIP to space for cultural production and dissemination. The planning context thus does not reflect a proactive attempt to channel development activity toward the provision of cultural community benefits.

Two developments in the City database of $\mathrm{s.37}$ agreements relate to the Artscape Sandbox development. The main contribution comes from the Cinema Tower development, which provided a performance space constructed to a minimum value of $\$ 1,000,000$. A further $\$ 500,000$ was secured from an un-related development at King Street West and Peter Street. A final contribution of $\$ 100,000$ was secured in 2015 (Artscape, personal communication, February 22, 2016), and consequently does not yet appear in the City database.

\subsubsection{How the s. 37 Agreement Occurred}

In its thirty year history, Artscape has followed a number of different paths to realise its various art space developments. Some projects are strategic goals that Artscape pursues over many years while it searches for the right site or funding opportunity. Other opportunities arise unexpectedly, and the Sandbox certainly falls into the latter category. Though it was in no way "off mission" for the organisation, Artscape was not actively looking to build a theatre in Toronto's Entertainment District when the opportunity presented itself (Artscape, personal communication, February 22, 2016). 
The project vision for the Sandbox evolved as a reflection of the three key parties to the agreement. The developer had an interest in incorporating cultural uses into its redevelopment project. For its part, Artscape considered this proposal a rare opportunity to acquire its first space in the downtown core (Artscape, personal communication, February 22, 2016). Then-Councillor Adam Vaughan also had an interest in securing affordable, community-oriented performance space in a neighbourhood dominated by major commercial institutions like Mirvish Productions. The Councillor's priority has since been reiterated in Culture Division consultations with arts and community stakeholders across Ward 20 (Toronto, 2014a).

Much like the Theatre Centre case study, the Sandbox story highlights the importance of political capital and organisational capacity to ensure the community benefit is a viable undertaking. Artscape participates in ongoing government relations work with local councillors to raise awareness of its cultural development goals, particularly in wards where the organisation is hoping to expand. In addition, Councillor Vaughan had served on Artscape's board of directors and was familiar with the organisation, its operations, and its capacity to take on a project of this scale (Artscape, personal communication, February 22, 2016). Artscape's track record was fundamental to ensure Daniels could partner on the project. A developer does not want to see the ground floor of its property underutilised or vacant for an extended period. Constructing theatres is therefore a particularly risky venture because these spaces do not easily convert to other uses in a scenario where the arts partner fails to assume management. As such, Daniels must ensure its not-for-profit partners have a track record of delivering arts uses and meeting the funding targets required to fully realise the space. ( $\mathrm{N}$. Haggart, personal communication, March 3, 2016).

The combination of a successful development track record and relatively robust capacity is likely unique to Artscape, particularly as it relates to the organisation's ability to respond when the nature of the project changes. The Sandbox that opened in 2015 is not the same facility that was conceived at the start of the s. 37 process. The original plan intended for Artscape to own the facility, while a single small or mid-sized theatre company would operate the venue as a sole tenant. To identify a tenant, Artscape initiated a broad outreach campaign that encouraged both its existing clients and other 
prospects in the theatre community to undergo an informal feasibility exercise. Notably, none of the theatre companies that took part believed it would be possible to generate the funds required to transform the base space provided by Daniels into a useable theatre. The original project vision did not align with the financial challenge of operating a not-for-profit theatre in Toronto. As such, Artscape developed a revised proposal that would allow the company to own and operate the space by renting it out to a larger number of small to mid-sized theatres. Affordable rental rates for arts groups would be subsidized in part through commercial rentals. In order to make the revised proposal possible, a second s. 37 contribution from a nearby development was directed to the Sandbox (Artscape, personal communication, February 22, 2016).

\subsubsection{The Influence of $\mathrm{s} .37$}

S. 37 funding made up a significant component of the Artscape Sandbox capital budget. The three agreements represent $77 \%$ of the nearly $\$ 2.1 \mathrm{M}^{3}$ project, and comprise the entirety of the City of Toronto's financial contribution to the capital budget.

Figure 5: Artscape Sandbox capital budget

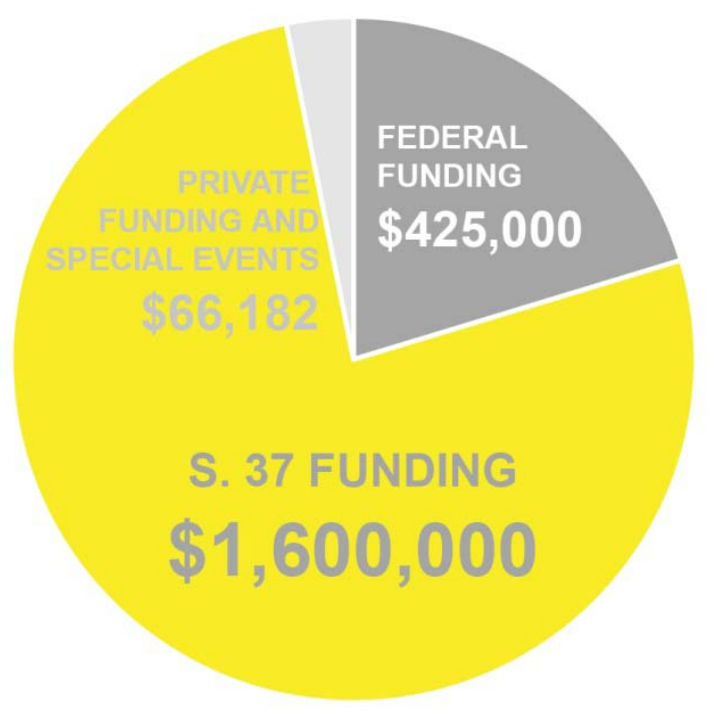
catalysed this development and created the opportunity for Artscape to pursue a project they would not otherwise have considered (Artscape, personal communication, February 22, 2016). However, the timing of the s. 37 funding demonstrates that it served not only as a catalyst but as a response to needs that emerged as the circumstances of the project changed. The second agreement for $\$ 500,000$ was negotiated by Councillor Vaughan when it became clear that Artscape would need to operate the venue. Similarly, the $\$ 100,000$ negotiated in 2015 by current Councillor Joe Cressy was secured to meet a funding gap when the project went over budget. Though Artscape is unique among arts organisations in Toronto, this use of $\mathrm{s}$.

\footnotetext{
${ }^{3}$ At the time of writing, $\$ 75,000$ of the federal funding contribution had applied for but not yet secured. The project also received in-kind support from suppliers that is not reflected in the capital budget.
} 
37 demonstrates the tool can have a multi-faceted impact on capital budgets for performing arts facilities.

\subsection{Case Studies: Emergent Themes}

The common themes that emerged from case interviews and content analysis signal important considerations for planners. For both the Theatre Centre and Artscape Sandbox, s. 37 funding was a catalytic factor for cultural development and the sole municipal funding mechanism for the project. Similarly, s. 37 funding was not only a catalyst but a necessity: the costs and risks associated with building a theatre make it unlikely that these projects would have been pursued without some form of incentive and regulatory support. Large scale developments require an arts partner with significant organisational capacity. The reliance on relationship building, as well as public and private sector partnerships, highlight the degree of social and political capital that s. 37 projects demand of arts workers. Finally, the nature of s. 37 agreements mean that these spaces fulfill broader policy goals in addition to their primary function of advancing the production and dissemination of arts and culture. S. 37 is often positioned, directly or indirectly, as a way to intervene in the market, mitigate against the impact of development, and animate communities.

Although Crow's Theatre was not able to participate in this study, these emergent themes feature prominently in the media articles about the company's new space at Dundas Street and Carlaw Avenue in Toronto's east end. The importance of a relationship with the ward councillor, as well as the transformative impact of s. 37 funding, is especially notable in media narratives. For example, Councillor Paula Fletcher is credited with fostering the partnership between Crow's Theatre and Streetcar Developments during negotiations over the ground floor uses in a proposed condo building (Mill, 2013). More than $\$ 1 \mathrm{M}$ of the capital budget for the new venue was funded through s. 37 , which amounts to between $11 \%$ and $14 \%$ of the project budget (Nestruck, 2013; Stage Door News, 2015). Notably, Crow's Theatre positions this support as a City endorsement for the project, and the gives s. 37 funding a prominent position in its project announcement (Crow's Theatre, 2013). The transformative nature of s. 37 funding is evident in the organisation's expanded mandate, which will result in increased community programming geared toward the growing but underserved arts market east 
of the Don Valley (Crow's Theatre, 2013; Mills, 2013). The project also marks a significant shift in how the company operates. The intent of this new space is to allow Crow's to become self-sustaining by using rental revenues to fund artistic production, thereby minimising its reliance on public funding (Nestruck, 2013).

Notably, these themes are also common to s. 37 culture projects that did not move forward past the agreement phase. Two s. 37 agreements in the City of Toronto database identify community spaces managed by the Toronto Arts Council ${ }^{4}$ (TAC), the municipal granting body for not-for-profit arts and culture initiatives. These small spaces, which would have been embedded in new developments, were secured by former Councillor and former TAC board member Adam Vaughan. However, in discussion with the City, the TAC agreed that it would not be feasible to assume management of these properties. The small footprints limited the utility of the spaces, and made it challenging to identify arts partners that could occupy the spaces under lease terms that would be manageable for the TAC. The TAC was also unsuccessful in identifying an institutional partner that might be able to share these spaces (S. Wright, personal communication, February 24, 2016). As in the case of Artscape Sandbox, the type of space that can be secured through s. 37 does not always align with the operational circumstances of arts companies or art space managers. Furthermore, the form these spaces take through $\mathrm{s}$. 37 negotiations may limit their capacity to serve broader policy goals. A small space is better geared to inwardly-focused activities like art creation or administrative uses, rather than dissemination activities that are community-oriented and can contribute to goals like animating streets and public spaces.

Ultimately, despite the opportunity that s. 37 presented, the TAC determined that taking on management of these spaces would constitute "mission creep" - the TAC, after all, is a granting body not a property manager (S. Wright, personal communication, February 24, 2016). However, although the City of Toronto is concerned with the provision of an adequate supply of affordable cultural spaces, it is not interested in owning any additional theatre venues (L. Martin, personal communication, March 4, 2016). This suggests that future cultural infrastructure development will rely on proactive partnerships between not-for-profit performing arts groups and the private sector.

\footnotetext{
${ }^{4}$ The author has been a member of the TAC Board of Directors since December 2014.
} 
Artscape has historically assumed a great deal of responsibility in the creation and management of new spaces for arts and culture in Toronto. The company has said it would welcome new arts groups that want to pursue art space development (Artscape, personal communication, February 22, 2016). However, the current capacity issues within the sector may make it unlikely that a new, not-for-profit art space manager will emerge in the near future. It is also important to acknowledge that some arts groups may prefer to operate without a permanent venue. By keeping operation costs low, a company can direct more of its limited resources to art-making rather than property management. The current challenge is the sheer volume of small and midsized theatre companies, as well as ad-hoc performance collectives, relative to the number of affordable, adequately-equipped venues available to rent.

It is beyond the scope of this project to explain why cultural benefits are not more common in s. 37 agreements, though the case findings help to illustrate why performing arts facilities are less likely to be pursued by the parties in these negotiations. Study participants have suggested a number of possible reasons that $\mathrm{s}$. 37 funding is rarely accessed by the performing arts community. Two crucial barriers include a lack of awareness or understanding of planning tools, and a lack of capacity to pursue major capital projects. The arts community has traditionally had an uncertain relationship with development and developers, such that artists may feel they are being used to sell the properties that will ultimately displace them. Conversely, there may be few developers with the interest or resources to pursue a broader city-building agenda that engages with not-for-profit partners. The risks to both the artists and the developers cannot be understated. For an arts partner with limited revenue-generating ability, a capital campaign may exponentially increase their operating budget to unrealistic levels. A failed capital project could bankrupt a small company and potentially leave its board members personally liable for the development costs. Similarly, if the project was to fail, the developer would be left with a space built for such a specific use that it is nearly impossible to repurpose without considerable expense.

For its part, Toronto's Culture Division has learned a great deal about working with s. 37 since the 2003 culture plan was written. Experience has demonstrated how crucial it is to finesse the details of s. 37 agreements, particularly by establishing 
appropriate lease terms for the spaces. Building designs are now required to clearly delineate what area corresponds to the s. 37 benefit and what has been added to fully realise the not-for-profit's vision for its facility. Importantly, each s. 37 agreement is the result of a unique context, negotiation, and set of community needs. The process is complex and the model employed in one case will not likely be reproduced elsewhere in the city. That said, the lessons learned are invaluable when moving forward with new s. 37 negotiations (L. Martin, personal communication, March 4, 2016).

Culture Division's accomplishments have relied upon strong research and data analysis by both City staff and external researchers. As such, the studies and tools produced since 2003 - including the Millward report, the ward-by-ward Making Space for Culture consultations, and the From the Ground Up report containing the Cultural Location Index - help the Division tell Toronto's cultural planning story and integrate it with land use planning projects (L. Martin, personal communication, March 4, 2016).

This integration is apparent in a number of current Culture Division priority projects, suggesting great strides have been made since the contentious development process in the WQWT. For instance, a potential community hub project within the Garrison Common North Secondary Plan area is cited as an example of proactive and effective collaboration between City Planning and Culture Division (L. Martin, personal communication, March 4, 2016). In 2013, City Planning created a planning strategy for the South Niagara neighbourhood, a formerly industrial area steeped in history and heritage that is undergoing significant development pressure. Among the neighbourhood assets identified by the strategy is the Wellington Destructor, a Cityowned incinerator that has been vacant since 1986 (Carter-Shamai, Craig, Davis, Golovkin, Sotomayor, Tremblay, and Willett, 2015). Culture Division has been involved in the South Niagara Planning Strategy and in the growing enthusiasm to see the Destructor transformed into a community or cultural hub. This collaboration has created a wealth of planning directions that can inform future s. 37 investments in this potential creative space (L. Martin, personal communication, March 4, 2016). Recent developments like the Crow's Theatre project and a major new cultural hub development in the Weston-Mount Denis community similarly emerge from planning strategies and consultations that proactively identified the need for new cultural 
infrastructure. Support through s. 37 agreements feature prominently in both cases as an opportunity to realise cultural benefits.

The growing number of successful development applications that incorporate public benefits of a cultural nature may encourage developers to engage with artists and acknowledge the benefits of supporting the sector (L. Martin, personal communication, March 4, 2016). For the time being, however, proactive regulation remains necessary to encourage the private sector to pursue partnerships with the not-for-profit arts community. 


\subsection{Future Directions}

This project sought to determine who and what is relied upon to build new cultural spaces in the City of Toronto. The Theatre Centre and Artscape Sandbox case studies both underscore the significance of organisational capacity on the part of the arts group, combined with strong social networks that support the vision for a new cultural space. Relationships with supportive ward councillors who can facilitate development partnerships are especially important in both case study narratives. The amount and timing of the s. 37 contributions also influence the viability of new cultural developments. In both cases, this funding was supported by additional public and private sector contributions generated by the not-for-profit arts organisations. Finally, both cases reveal a nominal relationship between cultural planning goals and the land use planning context for each project. Planning tools like secondary plans were not employed to support cultural development. The opportunities emerged instead through community activism, developer interest, and/or councillor know-how, rather than proactive land use planning for current and future cultural needs.

The cases illustrate that s. 37 will continue to play a critical role in funding new cultural spaces, particularly within a policy climate that constrains the revenue generating potential of the property tax base. However, the cases also illustrate that new cultural development relies upon substantial contributions through s. 37. At present, these funding levels can only be generated by large-scale developments that are not common outside of the downtown core. Similarly, the business case for cultural investment is much stronger in downtown areas where creative industries and communities are more densely clustered, and where developers can generate higher returns on arts-friendly projects. It has taken many years for Artscape to finally identify an opportunity to expand its cultural development model to Toronto's inner suburbs. The forthcoming Weston Cultural Hub, which is set to open in 2018, is just one component of a much broader revitalisation strategy that has been in the works since 2010 . This suggests that proactive and concerted planning intervention is required in order to create the enabling conditions that support cultural development in the suburbs.

Cultural investment in Toronto's suburban neighbourhoods will not come quickly or easily. The current reliance on s. 37 funding could exacerbate inequalities by 
burdening already under-serviced communities with significant fundraising targets, complex projects, and relationship-building challenges. Research has already demonstrated Toronto's pre-amalgamation suburbs have higher proportions of lower income households and new immigrants (Hulchanski, 2010), as well as some of the lowest levels of voter participation in municipal elections (Siemiatycki and Marshall, 2014). These findings suggest that the ties between City Hall and underserviced communities are not strong. As such, the political and social capital requirements that feature so prominently in both the Theatre Centre and Artscape examples are problematic when the s. 37 model is extended to the suburbs. A councillor or developer who has little experience with s. 37 agreements and/or the culture sector may be less likely to pursue cultural projects as community benefits. It is unrealistic to place the burden of cultural infrastructure development on communities that may not have the capacity, means, or networks required to ensure these projects are successful.

These research findings suggest a number of directions for further action and study that will enable land use planners to better support Toronto's cultural development goals:

\subsection{Reinvent the Relationship between Land Use and Cultural Planning}

It is beyond the scope of a graduate research paper to recommend sweeping changes to the structure of the City of Toronto. However, the separation between the infrastructure of culture and the practice of culture at the City currently poses a barrier to the effective use of $\mathrm{s} .37$ agreements to secure new cultural infrastructure.

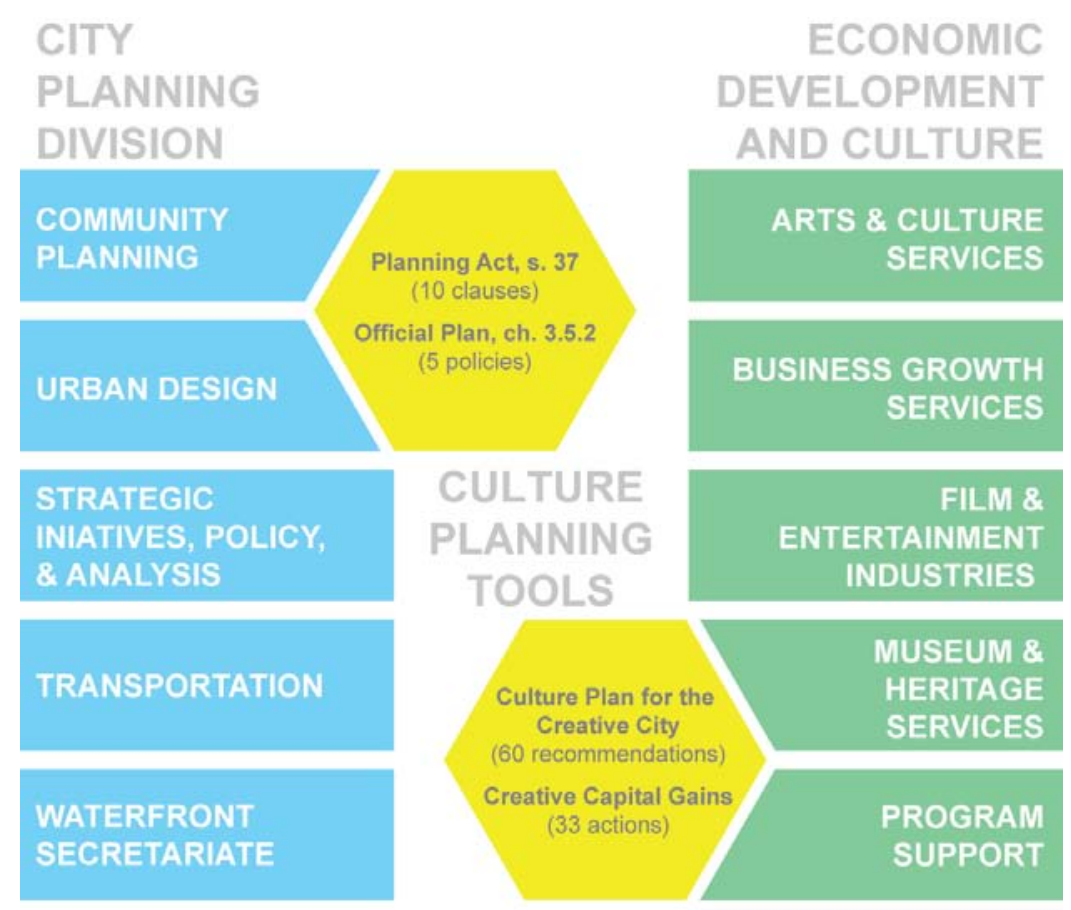


Although both the City Planning Strategic Plan (Toronto, 2013b) and the Culture Plan for the Creative City (Toronto, 2003) argue for greater inter-divisional cooperation, the portfolios of City Planning and Economic Development and Culture are largely discrete. While the culture plans build upon the policy vision set out in the official plan, it is difficult to ascertain the extent to which they are components of development review, or whether planners are required to give them any consideration when making land use planning decisions. The cultural planning tools in s. 37 of the Planning Act and Chapter 3.5.2 of the official plan have a narrow scope relative to the combined 93 recommendations in the 2003 and 2011 culture plans. Furthermore, recommendations in the culture plans are largely targeted to Culture Division staff, focusing on internal changes instead of proposing new behaviours for other departments.

Greater integration between planning and culture will require more substantial direction. For instance, when the City of Chicago developed its 2012 culture plan, the recommendations included a directive to establish a cultural point-person in all City departments, and to implement culture-specific performance measures for all departments and agencies (City of Chicago, 2012). The City of Toronto should look to best practices established in other creative cities to find meaningful ways to bridge the divide between planning and culture.

The findings of this report highlight how critical it is for Toronto planners to take a more active role in culture sector issues. S. 37 is a land use planning tool; it has also played a tremendously important role in catalysing and funding new cultural infrastructure development, particularly given the current constraints on municipal budgets. If $\mathrm{s}$. 37 continues to be a singular municipal funding source for new cultural capital projects, then land use planners will have a tremendous influence on the ongoing health and vitality of the culture sector.

The time has come for planners and planning educators to stop treating cultural planning as a niche discipline. Toronto's planning documents take an instrumental approach to the culture sector, relying upon creative assets for both community development goals and to enhance the city's global competitiveness. Arts and culture are therefore no less vital than parks, schools, and community services - infrastructure for which land use planners currently reserve space as cities grow and intensify. Land 
use planning would benefit from a value shift with respect to the importance of cultural development and infrastructure.

\subsection{Make Proactive Use of Existing Planning Tools}

Financial constraints have historically demanded arts organisations make creative and innovative use of scarce resources. Land use planners could support the culture sector by taking the same kind of initiative and making proactive use of existing planning tools.

The City's official plan and its implementation guidelines for s. 37 contain provisions that can target funding toward specific community benefits. Yet these mechanisms are rarely employed: of Toronto's 34 in-force secondary plans, only four plans contain provisions that direct density incentives to support arts or cultural uses. Given the importance of s. 37 to cultural infrastructure development, planners should support the sector by making full use of the tools available and creating the enabling conditions for new cultural development in areas across the city. Proactive use of secondary plans and area policies could be especially useful in suburban areas where cultural development is not likely to happen without government intervention. Clear plans and policies can also help make the currently ad hoc benefit negotiations more predictable, thereby strengthening the regulatory capacity of s. 37 .

Toronto's official plan also allows s. 37 to be used irrespective of the size of the development where a secondary plan or area policy contains the appropriate provisions. These provisions could be incorporated in plans across the city to ensure a greater number of communities are able to benefit from s. 37 agreements, particularly in areas where the current height and density requirements to trigger a s. 37 negotiation are inappropriate. Culture Division could similarly develop secondary culture plans that offer a fine-grained, locally-focused analysis of cultural issues. Secondary culture plans could be valuable guides to help land use planners integrate cultural needs in new secondary plans. In particular, cultural planners may be uniquely positioned to address the ecological impact of cultural amenities that may otherwise be missed in neighbourhood or ward level analyses of community need. 


\section{$\underline{5.3 \text { Close the Research Gaps }}$}

This paper is decidedly silent on the question of how well s. 37 has served the arts sector because there is not enough data to make an informed judgement. The quantitative data suggests s. 37 has had little impact because the occurrence rate of cultural benefits is very low. However, there is no readily accessible dataset that demonstrates how many cultural infrastructure projects have been constructed in Toronto over a given time period, or how they were funded. As such, there is no way to compare the occurrence rate of s. 37 projects to the occurrence rate of cultural infrastructure projects funded through other sources. Similarly, the full scope of the impact of s. 37 funding cannot be gauged simply by counting benefits and agreements. Nuanced research is required to determine how many art projects have been enabled, how many audience members have been reached, and how local economies have benefited from cultural projects funded through s. 37 agreements. The reach of s. 37 is likely quite broad, but additional study is required to accurately quantify its impact.

Similarly, it is beyond the scope of this project to make a value judgement about s. 37 funding. The two case study performing arts facilities benefited tremendously from the planning tool. However, the other benefits considered by the study highlight a tension between what can be secured through $\mathrm{s}$. 37 versus what is actually required to achieve broader policy goals. S. 37 is a complex process that requires participation from a number of City divisions. Without targeted intervention, the s. 37 model may not be reproducible in parts of the Toronto where new cultural infrastructure is most needed. Further research is warranted to consider what types of cultural infrastructure can be achieved in which contexts, and what other tools and strategies are available beyond s. 37 agreements to ensure land use planners are able to hold space for culture. 


\subsection{Concluding Thoughts}

This study has demonstrated that land use planners exert considerable influence on the health of Toronto's arts and culture sector. What it has not done is attempt to solve the legal, political, and theoretical problems associated with s. 37 agreements. Despite policy reviews at the municipal and provincial levels, there remains a great deal of contention over the policy and planning rationale for density bonuses, the ad-hoc negotiation processes that shape Toronto's s. 37 agreements, and the implementation standards currently used in the City of Toronto. Public finance tools require clarity and transparency, particularly in times of fiscal restraint when funding mechanisms may be subject to heightened criticism and political challenges. Like so many other public policy goals, the issue of cultural investment forces us to ask not only what we want from our city but what we are willing to pay for. Although s. 37 was never meant to be a sustained revenue stream, it appears to play that role for Toronto's culture sector by enabling municipal investment in new cultural infrastructure without tapping into the property tax base. As such, the conflicts surrounding s. 37 of the Planning Act have significant implications to the sustained growth and vitality of cultural communities.

At present, land use planning and cultural planning are discrete and separate disciplines. The time has come for a paradigm shift: planners need to acknowledge their role in Toronto's cultural ecology and determine how best to serve this dynamic sector. 


\subsection{Appendix A: Research Questions}

Semi-structured interviews were conducted as part of this project. These interviews included clarifying and follow up questions, but ultimately probed the following primary research questions:

1. Section 37 agreements are meant to provide community benefits to a neighbourhood. To the best of your knowledge, how was a performing arts facility identified as a community need in [neighbourhood name] or [ward number]?

2. Prior to the initiation of Section 37 negotiations, for how long had a new performing arts facility been a goal or priority for your organisation?

3. How was Section 37 first brought up as a funding opportunity for [name of cultural facility]?

4. When was Section 37 first raised as a funding opportunity?

5. In your opinion, did Section 37 act as a catalyst for this capital project?

6. Was the Section 37 contribution used to leverage other funding?

7. Would the capital project have gone forward without Section 37 funding?

8. Preliminary research has revealed that very few performing arts facilities have been constructed with the support of Section 37 funding. In your experience, why do you think that Section 37 is so rarely used to build performing arts facilities?

Research participants were given the opportunity to review and comment upon the sections of this paper that reference their contributions. This study was reviewed by the Ryerson University Research Ethics Board. 


\subsection{References}

\subsection{Primary Research}

This research project was informed by interviews with Artscape Toronto; Franco Boni, Artistic Director and General Director of the Theatre Centre; Niall Haggart, Executive Vice President at the Daniels Corporation; Lori Martin, Senior Cultural Affairs Officer at the City of Toronto. Database fact-checking was also undertaken in conversation with Susan Wright, Deputy Director of Toronto Arts Council. These invaluable contributions were an instrumental part of this process.

\subsection{Maps}

Figure 2: Section 37 agreements that name cultural benefits [map]. Data layers: City of Toronto, City wards; City of Toronto, cultural spaces; City of Toronto, regional municipal boundary; City of Toronto, Toronto Centreline (TCL); Davis, from J. Biggar \& City of Toronto, Section 37 cultural spaces [computer files]. Ryerson University, Toronto, ON: Generated by Meaghan Davis, February 16, 2016. Using: ArcGIS 10.2.2 for Desktop Advanced [GIS]. Version 10.2.2.3552. Redlands, CA: Esri, 2014. Adobe Illustrator CC. Version 18.0.0 (64-bit). San Jose, CA: Adobe Systems Incorporated, 2014.

Figure 3: Instances of benefits named in Section 37 agreements [map]. Data layers: City of Toronto, regional municipal boundary; Davis, from J. Biggar \& City of Toronto, Section 37 cultural spaces [computer files]. Ryerson University, Toronto, ON: Generated by Meaghan Davis, February 16, 2016. Using: ArcGIS 10.2.2 for Desktop Advanced [GIS]. Version 10.2.2.3552. Redlands, CA: Esri, 2014. Adobe Illustrator CC. Version 18.0.0 (64-bit). San Jose, CA: Adobe Systems Incorporated, 2014.

\subsection{Bibliography}

Advisory Group on Community Hubs. (2015). Community hubs in Ontario: A strategic framework \& action plan. Toronto, ON: Government of Ontario. Retrieved from: https://dr6j45jk9xcmk.cloudfront.net/documents/4815/community-hubs-astrategic-framework-and-action.pdf

Artscape. (n.d.). About Artscape [Webpage]. Retrieved from http://www.torontoartscape.org/about-artscape

Artscape. (n.d.). Artscape announces $\$ 9.7$ million in gifts towards $\$ 38$ million Daniels Spectrum [Webpage]. Retrieved from http://www.torontoartscape.org/news/artscape-announces-97-million-giftstowards-38-million-daniels-spectrum

Artscape. (n.d.). Artscape Launchpad [Webpage]. Retrieved from http://www.torontoartscape.org/artscape-launchpad

Artscape. (n.d.). Artscape Sandbox [Webpage]. Retrieved from http://www.torontoartscape.org/artscape-sandbox 
Artscape. (n.d.). Creative spaces partnership exchange [Webpage]. Retrieved from http://www.creativespacesto.ca/

Artscape Toronto. (n.d.). Using planning tools and incentives at Artscape Distillery Studios [Webpage]. Retrieved from http://artscapediy.org/Creative-PlacemakingToolbox/How-Can-I-Use-Planning-Tools-and-Incentives/Section-37.aspx

ArtsVote Toronto. (2014). Report card 2014 [Webpage]. Retrieved from http://www.artsvote.ca/reportcard2014/

Bain, A. L. (2003). Constructing contemporary artistic identities in Toronto neighbourhoods. The Canadian Geographer / Le Géographe canadien, 47 (3), 303-317. doi:10.1111/1541-0064.00024

Bain, A. L. (2013). Creative margins: cultural production in Canadian suburbs. Toronto, ON: University of Toronto Press.

Biggar, J. \& City of Toronto. (2014). Section 37 database [Dataset].

Bill 73: Smart Growth for Our Communities Act. (2015). $2^{\text {nd }}$ Reading Sept. 29, 2015, $41^{\text {st }}$ Legislature, $1^{\text {st }}$ session. Retrieved from the Legislative Assembly of Ontario website: http://www.ontla.on.ca/web/bills/bills_detail.do?BillID=3176

Brault, S. (2010). No culture, no future. (Kaplansky, J., Trans.). Toronto, ON: Cormorant Books.

Bridge, S. \& Lancaster, J. (2015, February 5). Toronto integrity commissioner asked to investigate Coun. Mark Grimes. CBC News Toronto. Retrieved from http://www.cbc.ca/news/canada/toronto/toronto-integrity-commissioner-asked-toinvestigate-coun-mark-grimes-1.2946984

Business for the Arts. (2011). Report on performing arts organizations from the 20092010 survey data [Web page]. Retrieved from http://www.businessforthearts.org/research/reports-publications/

Carter-Shamai, S., Craig, C., Davis, M., Golovkin, A., Sotomayor, A., Tremblay, D., \& Willett, C. (2015). Reimagining the Destructor: History and policy review. Unpublished report, Department of Urban and Regional Planning, Ryerson University, Toronto, Ontario, Canada.

City of Chicago. (2012). City of Chicago cultural plan. Chicago, IL: Author. Retrieved from http://www.cityofchicago.org/content/dam/city/depts/dca/Cultural\%20Plan/Chicag oCulturalPlan2012.pdf

City of Toronto. (2013). Austin - Toronto music city alliance partnership draft framework \& terms of reference. Toronto, ON: Author. Retrieved from http://www.toronto.ca/legdocs/mmis/2013/ed/bgrd/backgroundfile-63954.pdf

City of Toronto. (2013). City planning strategic plan 2013-2018. Toronto, ON: Author. Retrieved from http://www1.toronto.ca/City\%200f\%20Toronto/City\%20Planning/Home/Files/pdf/ S/strategicplan.pdf 
City of Toronto. (2003). Culture plan for the creative city. Toronto, ON: Author. Retrieved from:

http://www1.toronto.ca/city_of_toronto/economic_development_culture/cultural_ services/cultural_affairs/initiatives/files/pdf/creativecity-2003.pdf

City of Toronto. (2007). Implementation guidelines for Section 37 of the Planning Act and protocol for negotiating Section 37 community benefits. Toronto, ON: Author. Retrieved from http://www1.toronto.ca/city_of_toronto/city_planning/sipa/files/pdf/s37_consolidati on_080117.pdf

City of Toronto. (n.d.). John Street corridor improvements [Webpage]. Retrieved from http://www1.toronto.ca/wps/portal/contentonly?vgnextoid=a0584bf2970fb410Vgn VCM10000071d60f89RCRD

City of Toronto. (1998). King-Spadina community improvement plan: Public and private sector initiatives in support of continuing reinvestment in the King-Spadina area. Toronto, ON: Author.

City of Toronto. (n.d.). King-Spadina secondary plan. Toronto, ON: Author. Retrieved from http://www1.toronto.ca/planning/16-king-spadina.pdf

City of Toronto. (2014). "Making Space for Culture" final report: Creative Capital Gains (implementation action \#10). Toronto, ON: City Clerk's Department. Retrieved from http://www.toronto.ca/legdocs/mmis/2014/ed/bgrd/backgroundfile-69084.pdf

City of Toronto. (2014). Section 37/45 community benefits secured. Toronto, ON: Author. Retrieved from http://www1.toronto.ca/City\%200f\%20Toronto/City\%20Clerks/Elections/Candidat es/Files/s_37_45_community_benefitsreportward_all_1998to10142014.pdf

City of Toronto. (2015). Toronto Official Plan. Toronto, ON: Author. Retrieved from the City of Toronto Website: http://www1.toronto.ca/static_files/CityPlanning/PDF/chapters1_5_dec2010.pdf

City of Toronto. (2007). West Queen West Triangle - Official plan and zoning by-law amendments - Final report. Toronto, ON: Author. Retrieved from http://www.toronto.ca/legdocs/mmis/2007/te/bgrd/backgroundfile-4716.pdf

City of Toronto, by-law, No. 225-2009, Amendment to General Zoning By-law No. 43886 (Feb. 25, 2009).

City of Toronto, by-law, No. 617-2010, Amendment to General Zoning By-law No. 43886 (June 9, 2010).

City of Toronto, by-law, No. 795-2008, Amendment to General Zoning By-Law No. 43886 (July 17, 2008).

City of Toronto, by-law, No. 804-2012, Amendment to Site Specific Zoning By-law 14312011 (June 8, 2012).

City of Toronto, by-law, No. 883-2009 (OMB), Amendment to General Zoning By-law No. 436-86 (June 25, 2009). 
City of Toronto, by-law, No. 921-2011, Amendment to Zoning By-law No. 617-2010 (July 14, 2011).

City of Toronto, by-law, No. 1166-2009 (OMB), Amendment to General Zoning By-law No. 438-86 (Jan. 8, 2009).

City of Toronto, by-law, No. 1178-2009 (OMB), Amendment to General Zoning By-law No. 438-86 (Jan 8, Sept. 24, and Oct. 29, 2008).

City of Toronto, by-law, No. 1431-2011 (OMB), Amendment to General Zoning By-law No. 438-86 (May 6, 2011).

Creative Capital Advisory Council. (2011). Creative capital gains: an action plan for Toronto. Toronto, ON: City of Toronto. Retrieved from http://www1.toronto.ca/city_of_toronto/economic_development_culture/cultural_ services/cultural_affairs/initiatives/files/pdf/creative-capital-gains-reportaugust9.pdf

Daniels Gateway. (n.d.). Cinema Tower, Toronto [Webpage]. http://www.danielsgateway.com/index.php/cinema-tower-toronto/

Daniels Homes. (n.d.). Getting to the heart of home building [Webpage]. Retrieved from http://danielshomes.ca/about-daniels/our-story

Development Act, Statutes of Ontario (1997, c. 27). Retrieved from ServiceOntario eLaws via Service Ontario e-Laws website: https://www.ontario.ca/laws/statute/97d27

Doumani, R. G., \& Foran, P.A. (2014). Ontario planning legislation \& commentary. Markham, ON: LexisNexis Canada.

Gladki Planning Associates. (2014). Section 37 review: Final report. Toronto, ON: City of Toronto. Retrieved from http://www.toronto.ca/legdocs/mmis/2014/pg/bgrd/backgroundfile-66994.pdf

Grodach, C. (2013). Cultural economy planning in creative cities: Discourse and practice. International Journal of Urban and Regional Research, 37(5), 17471765. doi:10.1111/j.1468-2427.2012.01165.x

Healy, B. [Brendan_Healy]. (2014, August 14). What I love about the new $@$ TheatreCentre is that it brings dignity to the questions that are being asked within. [Tweet]. Retrieved from https://twitter.com/Brendan_Healy/status/500005147259719680

Hill Strategies Research Inc. (2014). A statistical profile of artists and cultural workers in Canada. Hamilton, ON: Author. Retrieved from http://www.hillstrategies.com/content/statistical-profile-artists-and-culturalworkers-canada

Hill Strategies Research Inc. (2012). Municipal cultural investment in five large Canadian municipalities. Hamilton, ON: Author. Retrieved from http://www.creativecity.ca/database/files/library/Municipal_cultural_investments_ 5cities.pdf 
Holden, J. (2015). The ecology of culture: A report commissioned by the Arts and Humanities Research Council's Cultural Value Project. Wiltshire, UK: Arts and Humanities Research Council. Retrieved from:

http://www.theingeniousgroup.co.uk/websitefiles/ahrc_ecology_of_culture_(a)_12 022015153653.pdf

Hulchanski, J. D. (2010). The three cities within Toronto: Income polarisation among Toronto's neighbourhoods, 1970-2005. Toronto, ON: Neighbourhood Change Community University Research Alliance. Retrieved from http://www.urbancentre.utoronto.ca/pdfs/curp/tnrn/Three-Cities-Within-Toronto2010-Final.pdf

Jenkins, B. (2005). Toronto's cultural renaissance. Canadian Journal of Communication, 30(2), 1499-6642. Retrieved from http://www.cjconline.ca/index.php/journal/article/view/1417/1523

John Tory wants full review of section 37 contributions. (2015, January 15). CBC News Toronto. Retrieved from http://www.cbc.ca/news/canada/toronto/john-tory-wantsfull-review-of-section-37-contributions-1.2905379

Jones, B. (1993). Current directions in cultural planning. Landscape and Urban Planning, 26(1-4), 89-97. doi:10.1016/0169-2046(93)90009-3

Keenan, E. (2015, January 16). The peculiar uses of Section 37 - from public art to affordable housing. Toronto Star. Retrieved from:

http://www.thestar.com/news/gta/2015/01/16/the-peculiar-uses-of-section-37from-public-art-to-affordable-housing.html

Kelly, D., \& Enta, C. (2013). Use of section 37 in the City of Ottawa. Ottawa, ON: Soloway Wright LLP. Retrieved from http://www.solowaywright.com/sites/default/files/publications_section37inthecityof ottawa_june5_2013.pdf

Kitchen, H. M. (2002). Municipal revenue and expenditure issues in Canada. Toronto, ON: Canadian Tax Foundation, L'association Canadienne d'études fiscales.

Kloosterman, R.C. (2014). Cultural amenities: Large and small, mainstream and niche A conceptual framework for cultural planning in an age of austerity. European Planning Studies, 22(12), 2510-2525. doi:10.1080/09654313.2013.790594

Kovacs, J.F. (2011). Cultural planning in Ontario, Canada: Arts policy or more? International Journal of Cultural Policy, 17(3), 321-340. doi:10.1080/10286632.2010.487152

Lancaster, J. \& Bridge, S. (2015, January 15). Etobicoke residents say neighbourhood lost out on $\$ 100 \mathrm{~K}$ in negotiations with condo developer. CBC News Toronto. Retrieved from http://www.cbc.ca/news/canada/toronto/etobicoke-residents-sayneighbourhood-lost-out-on-100k-in-negotiations-with-condo-developer-

1.2901300 
Lehrer, U., \& Wieditz, T. (2009). Condominium development and gentrification: The relationship between policies, building activities and socio-economic development in Toronto. Canadian Journal of Urban Research, 18(1), 140-161. Retrieved from http://www.uwinnipeg.ca/ius/docs/cjur/LehrerAndWiediz2009.pdf

Lintern, G. (n.d.). The "Kings Regeneration" Initiatives. Ottawa, ON: Canadian Mortgage and Housing Corporation. Retrieved from http://www.cmhcschl.gc.ca/en/inpr/su/sucopl/upload/The-Kings-Regeneration-Initiative-TorontoOnt.pdf

Maga, C. (2014, March 19). There's no place like the Theatre Centre's new home. Torontoist. Retrieved from http://torontoist.com/events/event/theres-no-place-likethe-theatre-centres-new-home/

Marsland, J. (2013). Shared platforms and charitable venture organizations: a powerful possibility for a more resilient arts sector. Toronto, ON: Metcalf Foundation. Retrieved from http://metcalffoundation.com/wpcontent/uploads/2013/06/Shared-Platforms-and-CVOs.pdf

Martin Prosperity Institute et al. (2011). From the ground up: Growing Toronto's cultural sector. Toronto, ON: City of Toronto. Retrieved from http://www.toronto.ca/legdocs/mmis/2011/ed/bgrd/backgroundfile-41204.pdf

McDonough, A., \& Wekerle, G. R. (2011). Integrating cultural planning and urban planning: The challenges of implementation. Canadian Journal of Urban Research, 20(1), 27-51. Retrieved from http://ezproxy.lib.ryerson.ca/login?url=http://search.proquest.com/docview/91547 9804? accountid=13631

Ministry of Municipal Affairs and Housing. (2010). Height and density bonusing (s. 37) [Webpage]. Retrieved from http://www.mah.gov.on.ca/Page6845.aspx

Ministry of Municipal Affairs and Housing. (2014). Provincial Policy Statement. Toronto, ON: Author. Retrieved from the Ministry of Municipal Affairs and Housing website: http://www.mah.gov.on.ca/AssetFactory.aspx?did=10463

Ministry of Tourism, Culture, and Sport. (2015). Telling our stories, growing our ecnomy: Developing a culture strategy for Ontario discussion paper. Toronto, ON: Author. Retrieved from http://www.mtc.gov.on.ca/en/publications/Culture_Strategy_Discussion_Paper.pd f

Moore, A. A. (2013). Trading density for benefits: Section 37 agreements in Toronto. Toronto, ON: The Institute on Municipal Finance and Governance at the Munk School of Global Affairs. Retrieved from http://munkschool.utoronto.ca/imfg/uploads/221/imfg_perspectives_moore_(fe b_2013).pdf

Moore, A. A. (2013). Trading density for benefits: Toronto and Vancouver compared. Toronto, ON: The Institute on Municipal Finance and Governance at the Munk School of Global Affairs. Retrieved from 
http://munkschool.utoronto.ca/imfg/uploads/221/imfg_perspectives moore_(fe b_2013).pdf

Municipal Cultural Planning Inc. (2011). Municipal cultural planning: A toolkit for Ontario municipalities. Retrieved from http://www.ontariomcp.ca/toolkits/MunicipalCulturalPlanning_AToolkitForOntario Municipalities_digital.pdf

Neuman, W.L. \& Robson, K. (2012). Basics of social research: qualitative and quantitative approaches (2nd Candian ed.). Toronto, ON: Pearson Canada Inc.

Planning Act, Revised Statutes of Ontario (1990, c. P.13). Retrieved from ServiceOntario e-Laws via the Ministry of Municipal Affairs and Housing website: http://www.e-laws.gov.on.ca/html/statutes/english/elaws_statutes_90p13_e.htm

The Planning Partnership. (2006). King-Spadina Secondary Plan Review. Toronto, ON: City of Toronto. Retrieved from http://www1.toronto.ca/wps/portal/contentonly?vgnextoid=43a50621f3161410 Vgn VCM10000071d60f89RCRD

R.E. Millward \& Associates Ltd. (2013). Securing cultural benefits: Approaches to the use of Section 37 for arts and culture facilities. Toronto, ON: City of Toronto. Retrieved from http://www.toronto.ca/legdocs/mmis/2013/ed/bgrd/backgroundfile62975.pdf

Sandals, L. (2013, August 6). Condos: Boon or blight for the Toronto arts scene? Canadian Art. Retrieved from http://canadianart.ca/features/toronto-condos-story/

Siemiatycki, M., \& Marshall, S. (2014). Who votes in Toronto municipal elections? Toronto, ON: Maytree. Retrieved from http://maytree.com/wpcontent/uploads/2014/10/Who_Votes-final.pdf

Stolk, J. (2016, January 31). After the chil [Blog post]. Retrieved from http://www.creativetrust.ca/blog/

Theatre Centre. (n.d.). About [Webpage]. Retrieved from http://theatrecentre.org/?p=3656

Theatre Centre. (n.d.). Our new home [Webpage]. Retrieved from http://theatrecentre.org/?p=3686\&preview=true

Toronto Arts Council. (2013). Historic motion passed: City to invest \$6 million in arts and culture [Press release]. Retrieved from http://torontoartscouncil.org/news/historicmotion-passed-city-to-invest-\$6-million-i

Toronto Arts Council. (2013). Toronto Arts Council priorities for new funding 2013-2016. Toronto, ON: Author. Retrieved from http://torontoartscouncil.org/TAC/media/tac/Advocacy/Toronto-Arts-CouncilPriorities-for-New-Funding-2013-2016.pdf

Toronto Mayor's Economic Competitiveness Advisory Committee. (2008). Agenda for prosperity. Toronto, ON: City of Toronto. Retrieved from http://www.buildtoronto.ca/sites/default/files/files/agenda-prosperity-report.pdf 
Toronto Real Estate Board. (2016). Toronto real estate board MLS® home price index. Toronto, ON: Author. Retrieved from http://www.trebhome.com/MARKET_NEWS/home_price_index/pdf/TREB_MLS_ HPI_Public_Tables_0116.pdf

Urban Toronto. (n.d.). Cinema Tower [Webpage]. Retrieved from http://urbantoronto.ca/database/projects/cinema-tower

Whyte, M. (2015, April 4). Drawing the line on cultural development in Toronto. Toronto Star. Retrieved from http://www.thestar.com/entertainment/visualarts/2015/04/04/drawing-the-line-oncultural-development-in-toronto.html

York University. (2008). Policy timeline [Web page]. Retrieved from http://www.yorku.ca/robarts/torontoculturalpolicy/timeline.html 